\title{
In vitro models of cancer stem cells and clinical applications
}

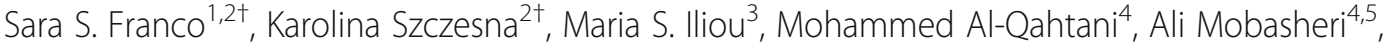 \\ Julianna Kobolák ${ }^{2}$ and András Dinnyés ${ }^{1,2,6^{*}}$
}

From 3rd International Genomic Medicine Conference

Jeddah, Saudi Arabia. 30 November - 3 December 2015

\begin{abstract}
Cancer cells, stem cells and cancer stem cells have for a long time played a significant role in the biomedical sciences. Though cancer therapy is more effective than it was a few years ago, the truth is that still none of the current non-surgical treatments can cure cancer effectively. The reason could be due to the subpopulation called "cancer stem cells" (CSCs), being defined as those cells within a tumour that have properties of stem cells: self-renewal and the ability for differentiation into multiple cell types that occur in tumours.

The phenomenon of CSCs is based on their resistance to many of the current cancer therapies, which results in tumour relapse. Although further investigation regarding CSCs is still needed, there is already evidence that these cells may play an important role in the prognosis of cancer, progression and therapeutic strategy. Therefore, long-term patient survival may depend on the elimination of CSCS. Consequently, isolation of pure CSC populations or reprogramming of cancer cells into CSCS, from cancer cell lines or primary tumours, would be a useful tool to gain an in-depth knowledge about heterogeneity and plasticity of CSC phenotypes and therefore carcinogenesis. Herein, we will discuss current CSC models, methods used to characterize CSCS, candidate markers, characteristic signalling pathways and clinical applications of CSCs. Some examples of CSC-specific treatments that are currently in early clinical phases will also be presented in this review.
\end{abstract}

Keywords: Cancer stem cells, Cancer, In vitro models, Cancer therapy

\section{Background}

Despite years of intensive experimental efforts and development of several novel treatment strategies, cancer is still a leading cause of mortality. New knowledge of the fundamental mechanisms underlying initiation of carcinogenesis can lead to a dramatic shift in the field of cancer research and treatment. This innovative understanding combines cancer and stem cell biology. The hypothesis that cancer is caused by the expansion of a population of cells with stem cell characteristics has attracted considerable attention [1-3]. The model suggests a hierarchical organization of tumour cells, with

\footnotetext{
* Correspondence: andras.dinnyes@biotalentum.hu

${ }^{\dagger}$ Equal contributors

'Szent István University, Gödöllö, Hungary

2Biotalentum Ltd., Gödöllö, Hungary

Full list of author information is available at the end of the article
}

self-renewal and differentiation abilities, that are capable of regenerating a new tumour in vivo with the same heterogeneity as the primary tumour [1]. This type of cells, identified as CSCs or tumour-initiating cells, possess unrestrained proliferative abilities, resistance to apoptotic cues, and aptitude to establish tumours in immunodeficient mice $[4,5]$. The cellular hierarchy was first identified in hematopoietic malignancies such as myelogenous leukaemia [6,7], and later on in solid tumours [4], based on the expression of specific cell surface molecules.

CSCs have been reported to be resistant to conventional chemo- and radio-therapy [8,9]; therefore, novel therapies integrating the current oncologic treatments should be identified and developed. The existing therapies generally target highly replicating cancer cells that constitute the bulk of the tumour but may not eradicate CSCs. For this reason, instead of trying to eliminate the 
bulk of the tumour or reduce its size, development of therapies aiming to eradicate the resistant CSCs would be a more efficient and rational approach [10]. Furthermore, it is important to identify and characterize CSCs in order to improve our knowledge about the biology of the tumour and carcinogenesis.

Identification of CSCs is a complex process and it relies on different strategies: expression of specific surface markers, in vitro assays such as anchorage-independent growth assays (tumour sphere assays) and in vivo limiting dilution assays, among others [11]. In this review, we will summarize the most recent cell-based in vitro models of CSCs and the promising clinical applications derived from these models, from biomarker discovery and microenvironment analysis to the identification of novel oncologic targets and therapies.

\section{History and current view of the CSC concept}

The CSC model suggests that a subset of cancer cells displaying self-renewal and pluripotency properties is responsible for the regeneration of malignant tissues and their homeostasis [10].

In 1875 Cohnheim proposed the first CSC hypothesis, also called the "embryonal-rest theory", that suggested the presence of embryonic-like cancerous cell remnants in adult tissues which develop into cancer in a nonspontaneous way [12]. In 1994 Dick and colleagues demonstrated that leukaemia initiating stem cells (LSCs), present in the blood of leukaemia patients, may induce acute myelogenous leukaemia (AML) when transplanted into severe combined immunodeficient (SCID) mice [6]. This was the first experimental evidence in support of the CSC theory, demonstrating the existence of cancer stem-like cells. A broad spectrum of cell surface stem cell markers (e.g. CD133, CD44, and CD24) allowed the identification of CSCs in human solid tumours, including brain, breast, prostate, pancreas, liver, ovary, skin and colon cancers, and melanoma [13-20] (Fig. 1).

Recently, two models that illustrate the organization of CSCs within the tumour have been proposed. According to the "stochastic model" (or "clonal evolution model"), initially described by Nowell and colleagues, every cancer cell in the tumour could gain the ability to self-renew and differentiate to the numerous and heterogeneous lineages of cancer cells that compromise the tumour. In this way, they were capable of repopulating the entire tumour [21]. On the other hand, the "hierarchy model" is based on the assumption that every tumour is a heterogeneous conglomerate of cancer cells and only a minority of them possess CSC properties [22].

During the past years, the origin of CSCs has been the centre of investigation, and in most cases it remains unknown and controversial, as shown by different studies on LSCs $[23,24]$. The identification of CSCs origin is very complex as the process of malignant transformation into CSCs may occur in different stages and within a very limited subpopulation of cells, therefore difficult to reach and study in detail. Nonetheless, the literature suggests adult stem and/or progenitor cells as the potential cell of origin of CSCs [10]. Adult stem cells are long lived cellular reservoirs with the mission to replenish damaged/senescent cells contributing to tissue homeostasis. According to Feinberg's "epigenetic progenitor model of human cancer" these cells live long enough to accumulate genetic and epigenetic changes that help them rearrange their microenvironment in such a way so that they can promote the origin of CSCs [25].

Normal adult stem cells have an ability to immortalize themselves via self-renewal and to generate mature cells of appropriate tissue through differentiation. Biology of stem cells is a relevant source of knowledge for cancer studies because of the similarities in the mechanisms that regulate self-renewal of normal (adult) stem and cancer cells [26]. Indeed, normal adult stem cells and CSCs share many characteristics. In addition to i) self-renewal and differentiation properties via asymmetric division, ii) CSCs and adult stem cells rely on the same signalling pathways; like Wnt, Hedgehog, Notch, among others, to control self-renewal, iii) they have similar metabolism (showing preference to oxidative glycolysis), iv) they express ATP-binding cassette (ABC) efflux transporters that protect cells from toxic compounds, v) express similar surface markers such as CD133 and CD44, vi) have enhanced anti-apoptotic, DNA-repair and oxidative stress-protective mechanisms, vii) exhibit a slowcycling phenotype related to a quiescent state, viii) have similar genetic and epigenetic profiles, ix) have extended telomeres, and $\mathrm{x}$ ) exhibit long life spans $[27,28]$.

In order to comprehend the connection between CSCs and normal stem cells, the transcriptional program in intestinal stem cells and colorectal carcinoma [29], as well as lung stem cells and lung CSCs [30], were studied. Interestingly, both studies revealed a significant overlap in the gene expression profiles between the two types of cell populations, mainly associated with self-renewal, angiogenesis, migration, and anti-apoptosis. Moreover, some proteins highly expressed in embryonic stem cells (ESCs), such as PRC2-regulated genes and the transcription factors Klf4, Nanog, Oct4, and Sox2, are frequently present in poorly differentiated tumours with adverse clinical outcome [31, 32]. The importance of Nanog and Oct4 in cancer research is supported by the elevated expression of these transcription factors in lung and ovarian cancer cells, which results in drug resistance and promotion of the epithelial-mesenchymal transition (EMT) [32, 33]. Moreover, some groups suggest that CSCs could also originate from more committed progenitors that acquire stemness-related features as an effect of accumulation of epigenetic and/or genetic changes $[34,35]$. 


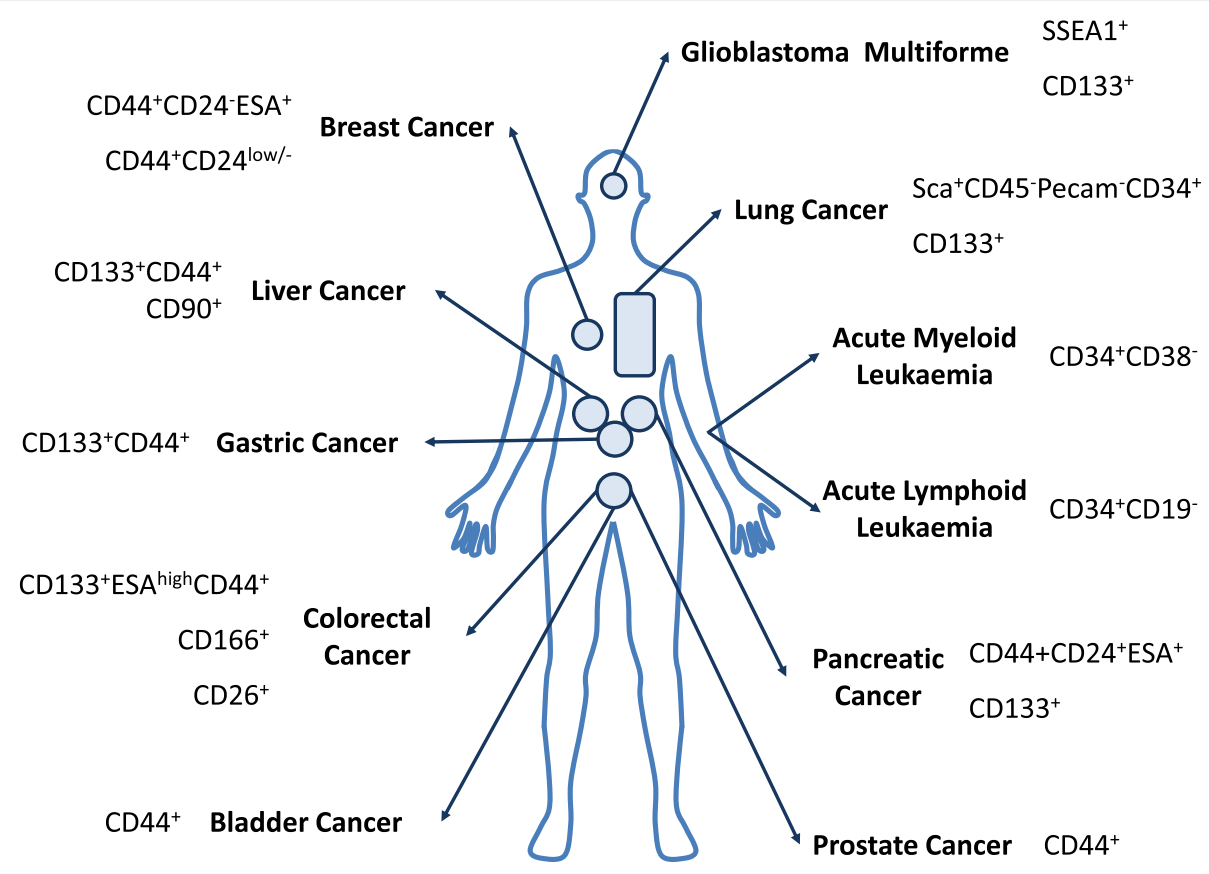

Fig. 1 Most common cell surface markers currently used to identify CSC subpopulations from different types of cancer

Metastasis, and not the primary tumour itself, is usually the main cause of death in cancer patients. Metastasis demands that cancer cells detach from the primary tumour site, travel systemically and form new tumours elsewhere in the body. Metastasis in cancer might be associated with the existence of a subpopulation of CSCs which initiate the formation of secondary tumours in distant organs and promote their proliferation, followed by the recruitment of new vasculature, or angiogenesis [36]. Although the current knowledge about the association of CSCs with metastasis is low, recent evidence supports the idea that EMT markers, known to be implicated in tumour cell migration, are expressed in CSCs [37]. These cells might be the precursors of the metastatic CSCs. Cancer cells might lose their epithelial characteristics by lack of polarity or intercellular adhesion, and gain mesenchymal properties followed by migration to different parts of the body [38]. In 2004 Yang and colleagues proposed EMT as being a required step in breast cancer metastasis [39]. In Scheel et al. (2011), the authors suggest that any given normal or neoplastic epithelial cell type utilizes the same network of paracrine and autocrine signals from the microenvironment in order to reach a certain EMT potential and maintain itself in a mesenchymal stem cell state with enhanced metastastic properties. In transplantation assays this is manifested by an increase of mammosphere forming cells with $\mathrm{CD} 44^{+} \mathrm{CD} 24^{-}$phenotype [40]. Many different genetic and epigenetic modifications contributing to adult stem and progenitor cell homeostasis can subsequently reprogram these cells to acquire some features that in conjunction with a potential "tumour promoting environment", may lead to cancer cells and CSC formation [3].

Proper elimination of CSCs might avoid cancer recurrence, and therefore, it is important for a successful cancer therapy. Indeed, CSCs are resistant to anti-tumour therapies, which preferentially eliminate cells with more differentiated phenotypes. This results in surviving CSCs that are responsible for tumour recurrence $[41,42]$. The most important evidence supporting the critical role of CSCs in tumour regeneration has emerged from breast cancer studies. In this type of cancer up to $25 \%$ of recurrences may appear after 10 years of the first successful therapy, and these cancers still have the properties similar to the primary tumours [43, 44]. This observation can be related with the presence of a small population of surviving CSCs more resistant to anti-tumour treatments than non-stem cancer cells that may be responsible for tumour relapse after initial successful therapy [9]. In a more recent study it was described that breast cancer metastasizes in bone marrow, where it acquires characteristics of slow cycling cells with enhanced chemoresistance and gap junctional intercellular communication (GJIC) common with the stroma [45].

\section{Cell-based models of CSCs}

Approaches to isolate the cancer stem-like cell population

Detection and quantification of CSCs can be carried out through in vivo or in vitro assays. The introduction of cells either from human primary tumours or 
cancer cell lines into immunodeficient mice, like nonobese diabetic severe combined immunodeficient (NOD/SCID) mice, offers a sensitive system to identify CSCs. Although this system is commonly used, it has some weaknesses, such as short life span of the mouse models, inadequacy of the CSC-specific cytokines and NK-driven residual innate immunity and failure to represent the tumour or disease microenvironment [46].

Quintana was first able to show that he can dramatically increase the sensitivity of the assay in recognizing CSCs by employing a "modified xenotransplantation assay", such as the NOD scid gamma (NSG) mice, which lack the interleukin-2 receptor gamma chain [47]. With this model, almost $25 \%$ of melanoma cells from patients were able to form new tumours in vivo. This implies that CSCs may not be as rare as previously estimated, highlighting at the same time the vital role of microenvironment in supporting tumour growth. Using this approach, Ishizawa et al. (2010) determined that the frequency of CSCs in many tumours is up to 10-fold higher in NSG mice, but generally it remained low (less than $0.04 \%)$ overall [48]. Similarly, Kuperwasser and colleagues employed genetically modified mouse models for breast cancer growth and metastasis, showing that species-specific stromal-niche interactions are critical for the in vivo growth and osteotropic metastasis of CSCs [49]. More "humanized" murine models should be employed in the future, which will be more permissive of implanted human cells to reconstitute their natural microenvironment [50].

By being a rare population within the tumour tissue, CSCs are difficult to isolate and study, which limits our ability to monitor the development and the pathogenesis of the cancer. This issue makes it necessary to develop cell-based models of cancer stem-like cells. Many in vitro assays for detection and identification of CSCs have been used, though a non-universal method can be applied [51]. The application of these CSC in vitro models has many benefits as it would permit the increment of our knowledge about CSCs, together with tumour biology, microenvironment, carcinogenesis, biomarker discovery, and could lead to improvement and progress of oncologic therapies, among other applications.

Recently published literature has employed different in vitro approaches to reach the CSC population. According to these publications, CSCs can be mainly obtained from cancer cell lines or primary tumours through i) reprogramming [32, 52-69], ii) the expression of specific surface markers $[15,70,71]$, iii) detection of the side population [72-78], iv) selection of cells resistant to anoikis [79], v) or based on the application of specific culture conditions, among other techniques [80-83].
Reprogramming of cancer cells as a way to model cancer Current cancer models are not sufficient to tackle the heterogeneity of human cancers. Animal models of cancer have been used for decades however, distinctions are observed between animal and human cancers. Cancer cell lines, although inexpensive and immortal, do not represent the primary tumour and disease progression, and they cannot easily be replaced by the primary cells isolated from tumours, that are limited and complex to maintain. In this way, in vitro models of carcinogenesis derived from reprogramming patients' cancer cells offer promise for the deciphering of the early mechanisms of the development and progression of cancers from pluripotent cells [84].

Historically, reprogramming back to pluripotency involved either blastocyst injection [85], or nuclear transfer (NT) [86], or lately, the exogenous forced expression of specific sets of transcription factors, known as "induced pluripotent stem cell (iPSC) technology" [32, 52-69] (see Table 1 for more details).

Similarly to normal somatic cells, human cancer cells have of late been successfully reprogrammed into a pluripotent state, as shown for gastrointestinal [57-60, 69], breast [62-64, 87], prostate [65], bone [61], liver [56], and lung $[32,54,55]$ cancers, melanoma $[52,53,88]$, and leukaemia [66-68]. By introducing nuclei from mouse melanoma cells into enucleated oocytes, Hochedlinger and colleagues (2004) established ESC lines from blastocysts, proving that cancer cells can be reprogrammed into a stem state disregarding the genetic aberrations. These ESCs had the potential to generate teratomas and to form chimeras that develop high penetrance melanomas [88]. Similarly, Blellock and colleagues were able to generate NT-derived ES cell lines from human embryonal carcinoma (EC) cells, with developmental potential similar to the respective donor EC cells [89].

In 2006 Yamanaka and Takahashi demonstrated that additionally to NT or blastocyst injection, nuclear reprogramming can be achieved by applying iPSC technology. Yamanaka's group established a panel of specific transcription factors, Oct4, Sox2, Klf4, and c-Myc (OSKM, or Yamanaka factors), which were previously shown to be oncogenic, with the ability to induce an ESC-specific gene expression module into somatic cells, converting them into pluripotent cells, the iPSCs [90]. This technology has been updated and applied effectively to somatic cells of many species, such as mouse [90], rat [91], rabbit [92], pig [93], rhesus monkey [94], and human [95-97], resulting in the generation of pluripotent ES-like cells with the capability to differentiate into cells of the three germ layers [90]. Similarly to normal somatic cells, malignant cells either from cancer cell lines [32, 52-55, 57-64, 66, 98, 99] or primary tumours [65, 67-69] from several cancer types have been successfully converted to iPS-like 


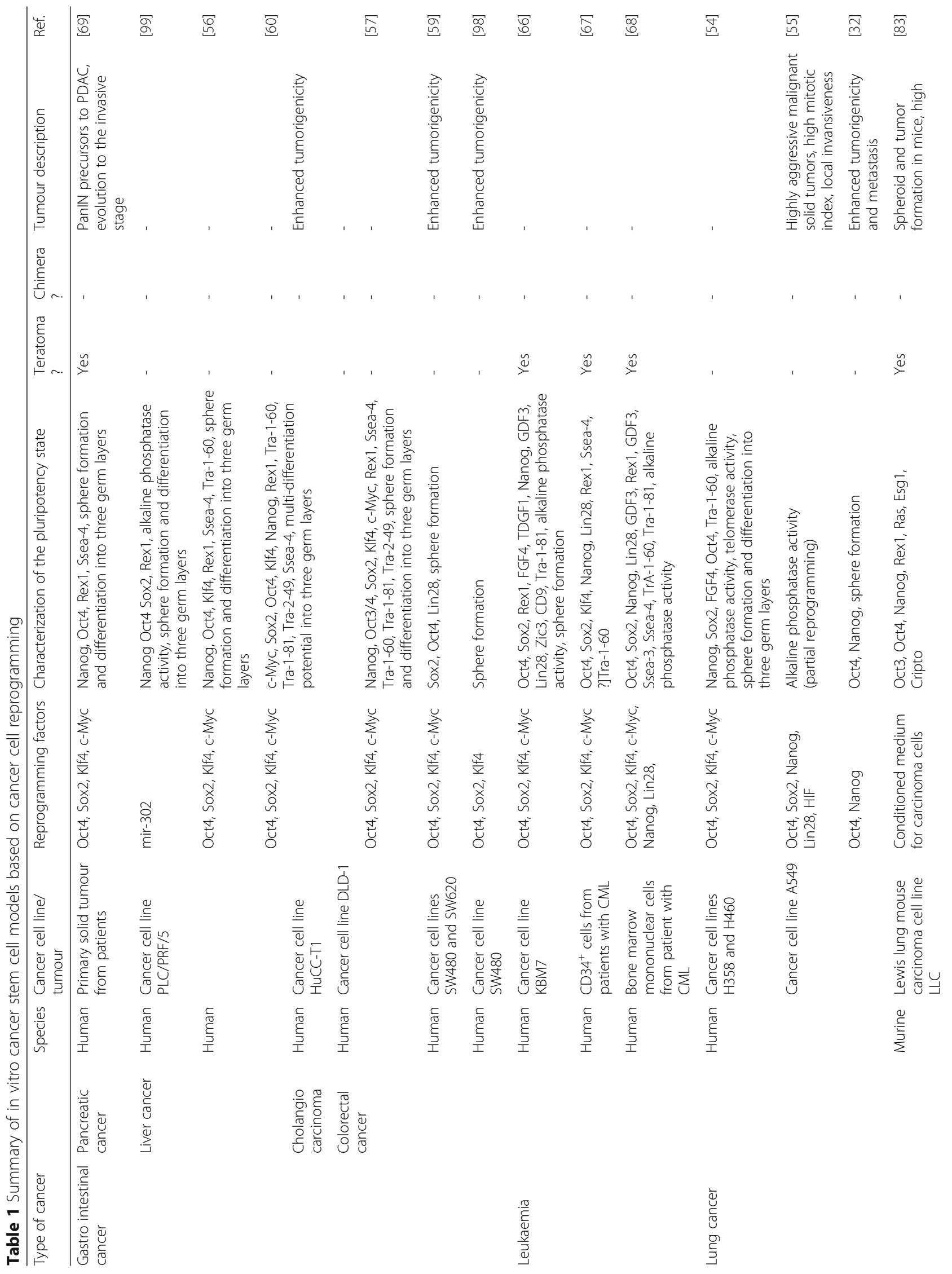




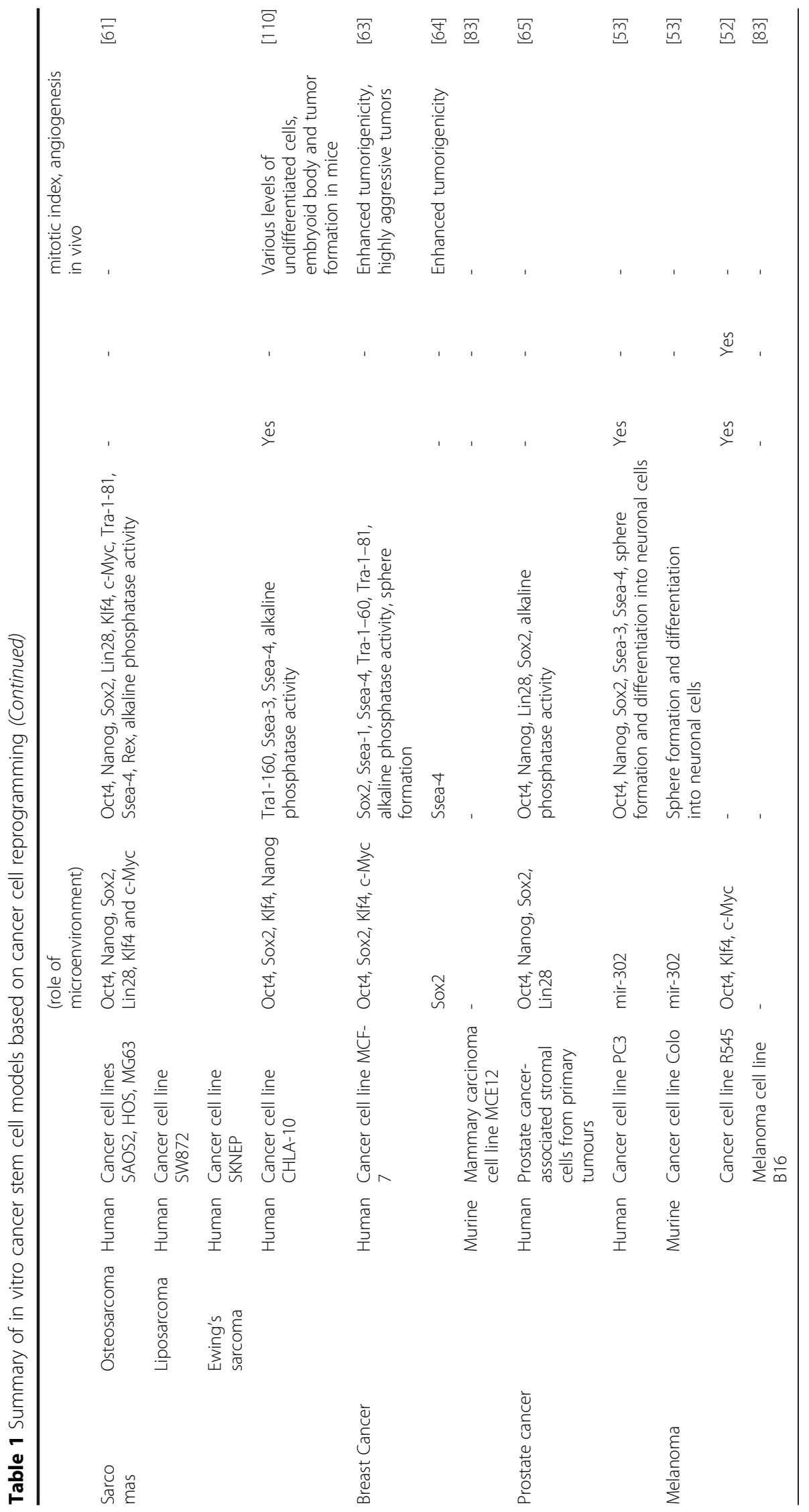


cells, or induced pluripotent cancer cells (iPCs) [55, 57, 66, 69] (Table 1).

In the last half-decade many research groups employed iPSC technology in their research involving human cancer cells, mainly through the overexpression of Oct4, Sox2, Klf4, and c-Myc factors [54, 57, 66, 69] (summarized in Table 1). The obtained reprogrammed cells are pluripotent as defined by all in vitro and in vivo criteria used to define pluripotent stem cells generated from somatic cells $[90,95]$, i.e. they express ESC markers, telomerase activity, have self-renewal abilities and are pluripotent by generating cells of all three germ layers; as shown by the formation of spheres in vitro, and teratomas in immunocompromised mice. When Oct4, Klf4, and c-Myc were overexpressed in a murine cancer cell line of melanoma, the generated iPCs were able to form viable chimeric mice after injection into blastocysts [52].

Although Yamanaka's set of iPSC factors are the most commonly used in research, the replacement of c-Myc and Klf4 with Nanog and Lin28 was implemented to human fibroblasts by Thomson's group, as c-Myc may cause death and differentiation of ESCs [95]. This new group of transcription factors, together with the overexpression of hypoxia-inducible factor (HIF) could convert lung cancer cells into partially reprogrammed cells capable of generating highly aggressive malignant tumours when injected into immunocompromised mice [55]. Alternatively, other groups have demonstrated that not all four transcription factors are required to reprogram cancer cells. This conclusion came from analysis of primary tumour specimens from patients. Chiou et al. (2010) showed that $\mathrm{CD} 133^{+}$lung CSCs co-express Oct4 and Nanog when compared to CD133 cancer cells. When overexpressed in A549 cancer cells, Oct4 and Nanog induced the formation of cancer stem-like cells and enhanced tumorigenesis and metastasis in mice [32]. A similar approach was used in breast cancer where early stages of carcinogenesis were linked with Sox 2 expression. When overexpressed alone in a breast cancer cell line, Sox2 stimulated the formation of spheres in vitro and tumour in vivo, demonstrating its function in the pluripotency preservation [62]. In other studies, Sox2 was dispensable in reprogramming of melanoma cells into iPSCs [52].

Alternative methods of reprogramming, where no integration in the genome occurs, have been published. In a study proposed by Ying and co-workers (2008), the family of microRNA (miRNA) miR-302, highly expressed in ESCs, was transfected into cancer cells generating ESlike pluripotent cells with self-renewal and multipotential differentiation properties [53]. A similar technology was successfully applied to hepatocellular carcinoma cells as shown by the group of Mori in 2014 [99]. On the other hand, reprogramming of cancer cells can be achieved through the application of small chemical molecules. When breast cancer cells were treated with valproic acid (VA), aldehyde dehydrogenase (ALDH)positive cells with a superior efficiency of mammosphere formation and tumorigenic ability were generated [100].

Though the iPSC process has been applied successfully to cancer cells from both primary tumours and cancer cell lines, it is time-consuming and less efficient compared to the reprogramming of non-tumorigenic somatic cells $[57,63,67,69,101]$. This observation may be due to the availability of certain number of cancer cells that contain a particular genetic and epigenetic status like aneuploidy or mutations in components involved in the epigenome [102]. Albeit a lower reprogramming efficiency has been described for cancer cells, some exceptions have been observed. Zhang et al. (2013) observed a slight augmentation of efficiency, probably associated with loss of pre-existing tumour suppressors [61]. As shown for normal somatic cells, the improvement of the reprogramming efficiency can be achieved through the overexpression of mir-302 [53] or HIF [55], deficiency of p53 [58] or Ink4/Arf [103], hypoxia [55, 58], or through the treatment with histone deacetylase (HDAC) inhibitors [e.g. azacitidine (5-azaC)] [104], VA [100], suberoylanilide hydroxamic acid (SAHA), or trichostatin A (TSA) [105]. When reprogramming factors were expressed together with HIF in lung cancer cells, the generated iPCs had enhanced tumorigenesis, showing the importance of hypoxia in the improvement of the reprogramming efficiency [55]. In 2009 Yamanaka proposed the "stochastic model", rather than the "elite model", to explain the low efficiency observed during the reprogramming process of normal somatic cells. Briefly, the "elite model" states the existence of a small population of cells that can be reprogrammed partially or completely. Alternately, the "stochastic model" states that most cells may undergo the process of reprogramming but just a minority completes it [106]. Lai and colleagues (2013) assessed this issue in reprogrammed cancer cells and concluded that the reprogramming process of these cells may follow the "elite model" [107]. According to the published results, only a small subpopulation of cells was selected for reprogramming as all obtained iPCs were free of mutations, unlike the parental cells. The contradictory results between iPSCs and iPCs may be related with the differences observed between normal somatic cells and cancer cells.

iPSCs tend to differentiate into the same tissue lineage from which they originate. Erasure of the epigenetic memory (methyl-DNA-marks) during factor-based reprogramming seems to be inefficient, leading to the maintenance of a "residual epigenetic memory" within the iPSCs [108]. Kim and colleagues performed a high- 
throughput array-based analysis of the methylome of iPS cells from different sources, in which they observed DNA methylation signatures reminiscent of the tissue of origin. Epigenetic memory may explain why bloodderived iPSCs differentiate with higher efficiency into blood when compared to fibroblast-derived iPSCs [108]. A similar observation was demonstrated for iPCs, which tend to generate the cancer type from which they are derived [69]. This can be due to a partial reprogramming of cancer cells. Although the reprogramming of cancer cells can generate cells with similar characteristics to ESCs, as shown by the transcriptome analysis undertaken by Mahalingam and co-workers [54], iPCs may not be so similar to ESCs as it was thought. In 2013 the group of Matushansky published an interesting work where the degree of differentiation reversion was evaluated after reprogramming sarcoma cells [61]. When the level of differentiation was compared, the gene expression and DNA methylation analysis denoted that reprogrammed sarcomas are closer to sarcomas and to partially reprogrammed fibroblasts than to fully reprogrammed fibroblasts and ESCs [61]. Similar conclusions were drawn by Menendez and colleagues (2013), where reprogrammed MCF-7 cells were in a status between differentiated cancer cells and iPSCs [63]. Taken together, these suggest that reprogrammed cancer cells seem to reach a "minimum state of differentiation" which is enough to confer them a pluri-differentiation potential. Alternatively, as suggested by Nagata et al. (2012), a pluripotent state may be achieved but not necessarily an ESC state [81].

Some groups have shown that reprogramming of cancer cells into a pluripotency state can decrease the tumorigenic capability of reprogrammed cells compared to parental cells $[52,54,57]$. This observation can be associated with the epigenetic reset that can drive the downregulation of the mechanisms (i.e. silencing of oncogenes) related with the tumorigenic behaviour of the cancer cells [54, 102]. In fact, a study by Wang and co-workers (2012) demonstrated that reprogrammed lung cancer cells hold a rectified epigenetic profile that may result in a reduction of the tumorigenic potential of these cells. The downregulation of genes usually expressed in non-small cell lung cancer (NSCLC) (e.g. KRT19 and S100P) might be associated with DNA methylation occurred during reprogramming, indicating the importance of DNA methylation to tumorigenesis [54]. This characteristic has become of interest for drug development and therapy. Moreover, when reprogrammed cancer cells are induced to differentiate into a germ layer diverse of the tissue from which they are derived, these cells lose the tumorigenic ability in vivo $[61,109]$. Hence, when glioblastoma-initiating cells were induced to differentiate into a mesoderm lineage, no malignant brain tumours developed in mice [109]. An analogous observation was made by Zhang et al. (2013). When reprogrammed sarcomas were terminally differentiated either into their own or into an alternate lineage of origin and inoculated in NSG mice, in both cases no tumours were detected [61].

Understanding the transitions among different states and acquiring the ability to exogenously manipulate the stemness and/or differentiation of normal but most importantly of tumours may hold promise as a therapeutic strategy in the near future (Fig. 2). In recent years, induced pluripotent stem cell reprogramming technology offered the possibility of generating clinically valuable pluripotent stem cells (named iPSCs) from fully differentiated somatic cells. The same reprogramming strategy is being now employed on cancer cell lines or patients' tumours (named induced pluripotent cancer stem cells or iPCSCs) (blue arrows in Fig. 2). iPCSCs cells epigenetically and transcriptionally resemble the ESC state and the cancer genome "seems to be repressed" in the pluripotent state. In some cases the iPCSCs may exhibit early stage phenotypes corresponding to partial expression of the reprogrammed cancer genome, constituting, in this way, a live cell model to study cancer progression [84]. Moreover, these iPCSCs have the ability to redifferentiate (orange arrow in Fig. 2) back to where they originated or other terminal differentiated cell lineage, losing along this process their tumorigenic and metastatic properties [110]. Alternatively, as it was shown in sarcomas, the induction to more differentiated state can occur directly from the adult tumour, in this case named "trans-differentiation" (dashed blue arrow), without the need to pass first from the pluripotent state [61]. In the case of sarcomas, it was shown that various types of sarcomas can be trans-differentiated into multiple mature connective tissues (dashed blue arrow in Fig. 2), abolishing their tumorigenic potential as measured by the ability to further proliferate in vitro (on soft agar) or in vivo (xenograft formation), without the need to be reprogrammed first in the ESC state [61]. Similarly, it was found that the epigenetic switch (mainly tumour suppressor hypo-methylation) in trans-differentiated glioblastomas inhibits their tumorigenicity when injected into mice [102]. Trans-differentiation of cancer cells to terminal differentiation via addition of chemical agents i.e. retinoids for acute promyelocytic leukaemia (APL) [111], peroxisome proliferator activated receptor gamma (PPARg) agonists for liposarcoma [112], or epigenetic drugs [113], could potentially be preferable with respect to clinical application compared to classical factor based reprogramming.

\section{Other cell-based models of CSCs}

Cancer cells with tumorigenic potential can be identified based on their capacity to form tumours when injected 


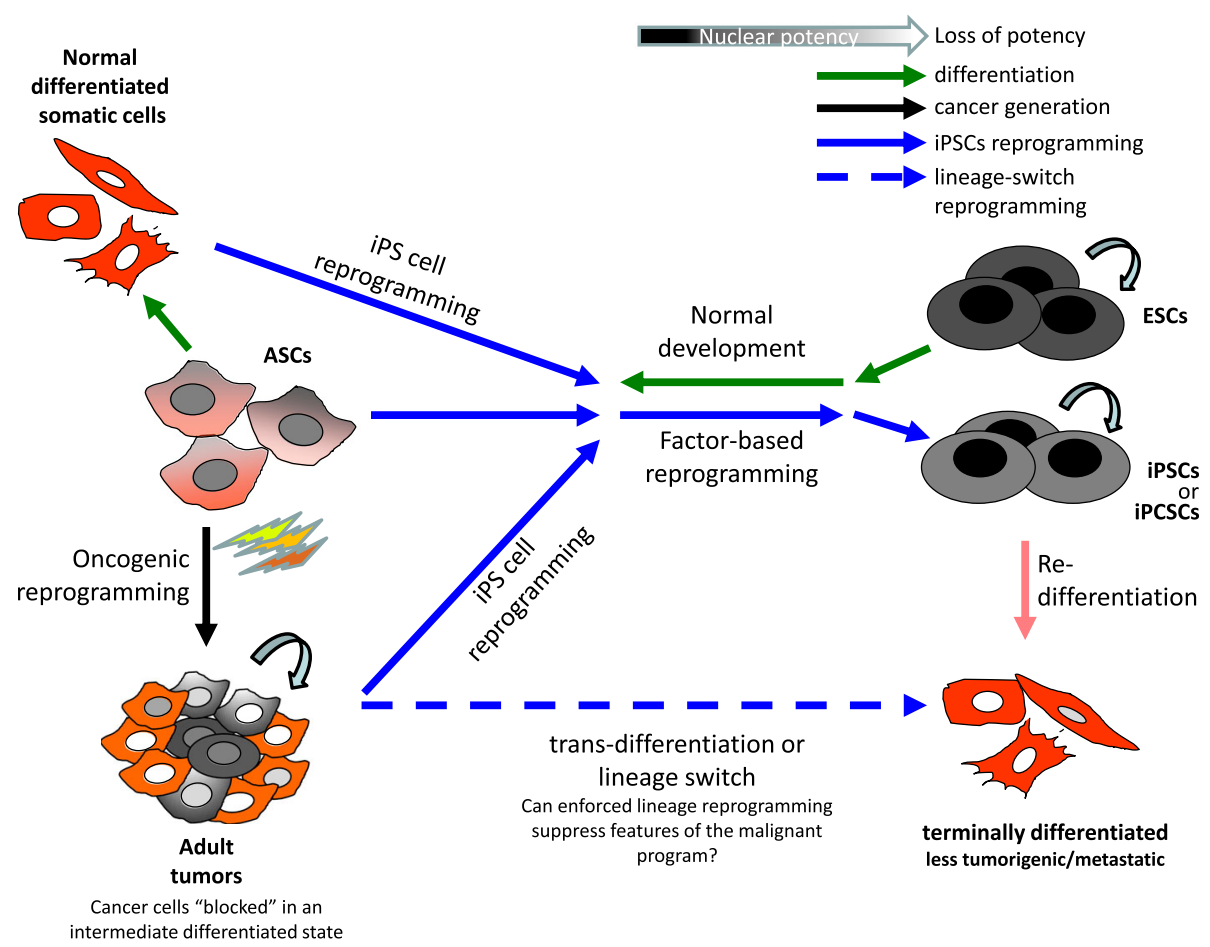

Fig. 2 Cancer stem cells reprogramming as an emerging tool in modelling cancer. The normal development (green arrows) denotes a passage from a pluripotent (zygote) to a "less potent state" (terminal differentiated adult tissues). During this process, adult stem cells (ASCs) in adult tissues suffer multiple tumorigenic "hits" that lead to the generation of "aberrantly reprogrammed" cancer cells, forced to be maintained in an intermediate degree of cellular differentiation (black arrow). Induced pluripotency is now being employed on cancer cell lines or patients' tumours (named induced pluripotent cancer stem cells or iPCSCs) (blue arrows). iPCSCs cells epigenetically and transcriptionally resemble the ESC state and the cancer genome seems to be repressed in pluripotent state. In some cases the PCSCs may exhibit early stage phenotypes corresponding to partial expression of the reprogrammed cancer genome, constituting in this way a live cell model to study cancer progression [69] (reviewed in [84]). Moreover, these iPCSCS have the ability to re-differentiate (orange arrow) back to the original or a different terminal differentiated cell lineage, losing along this process their tumorigenic and metastatic properties [110]. Alternatively, the induction to more differentiated state can occur directly from the adult tumour (in this case "trans-differentiation"-dashed blue arrow), without the need to pass first from the pluripotent state [61]. It is important to clarify the mechanisms controlling these transitions, as the ability to exogenously manipulate the stemness and differentiation of a tumour might hold promise as a therapeutic strategy in the near future

into mice. This approach allowed the isolation of the CSC population from breast tumours based on a specific phenotype of these cells, CD $44^{+} \mathrm{CD} 24^{-/ \text {low }}$ [1]. The idea to identify CSCs by flow cytometry comes from leukaemia where LSCs constitute a population of $\mathrm{CD} 34^{+} \mathrm{CD} 38^{-}$ cells capable of generating leukaemia in immunosupressed mice [114]. The prospect of CSC identification based on the expression of specific surface markers opened the way to their detection in other solid tumours: brain and lung $\left(\mathrm{CD} 133^{+}\right)$, prostate, gastric, and ovarian $\left(\mathrm{CD} 44^{+}\right)[13-15]$ cancers $[16,17]$, among others [18-20]. A more detailed description of the current surface markers used to identify CSCs can be found in Fig. 1 [reviewed by Allegra et al. (2014)] [2]. A unique combination of surface markers has not been identified so far as their universal application to most cancer types and subtypes is limited. Despite the fact that CD44 and CD24 are expressed in most tumours and are commonly used to identify CSCs, they are not specific to all cancers
[115], and in addition, they can be also found in ESCs. The identification of surface markers specific to CSCs has allowed their sorting from either cancer cell lines or primary tumours through cytometric-based technologies or immunomagnetic beads [70]. In a recent publication, $\mathrm{CD} 44^{+} \mathrm{CD} 24^{-/ \text {low }}$ breast $\mathrm{CSCs}$ were isolated from the MCF-7 cell line and evaluated for their resistance to known hormonal therapy. Results demonstrated that the breast CSC population was resistant to doxorubicin but not to tamoxifen [71]. Research undertaken by Takaish and colleagues identified a subpopulation of $\mathrm{CD} 44^{+}$cells within gastric cancer cell lines with stem cell properties, such as self-renewal ability and capacity to generate differentiated progeny, and increased resistance to chemo- and radio-therapy. This $\mathrm{CD} 44^{+}$population had tumorigenic potential both in vitro and in vivo, unlike CD44 cells [15]. Special care should be applied when evaluating the surface markers by flow cytometry as their integrity might be affected by the dissociation 
agents. When different digestive agents were compared with regards to their effect on the presence of CD44 and CD24 surface markers in a breast cancer cell line, differences were observed. Indeed, enzymatic digestion affects the identification of CSCs by flow cytometry; trypsin being more aggressive when compared to accutase [116]. Enzyme-free buffers or special tissue engineered surfaces coupled with temperature reduction could be considered as a replacement.

In addition to cell surface markers, the activity of intracellular enzymes, such as ALDH, can be used to enrich CSCs. The stem cell marker ALDH, a detoxifying enzyme highly expressed in stem cells [117], has been commonly used in the identification of CSCs. Charafe-Jauffret and colleagues (2009) evaluated several breast cancer cell lines to conclude that the majority were $\mathrm{ALDH}^{+}$and that this cell population possessed CSC properties [80]. Similar results were obtained for LSCs in AML [118] and malignant breast stem cells in breast cancer [119].

The fluorescent dye exclusion, or side population (SP) phenotype, is another property of stem cells that can be used to identify CSCs. Cells that extrude fluorescent dyes such as Hoechst 33342 are defined SP cells and can be easily identified by the flow cytometry technique. This characteristic is related to the high expression levels of $\mathrm{ABC}$ transporters family members, such as ABCG2 transporter. When the SP approach is applied to cancer cells, stem-like cells with tumorigenic abilities and resistance to chemotherapy are obtained [77, 78]. Indeed, ABC drug transporters have been shown to protect CSCs from chemotherapeutic compounds, a characteristic that could be useful for the development of new therapies against these transporters. Huang et al. (2009) identified in human esophageal carcinoma cell lines a subpopulation of cells with CSC properties with higher tumorigenicity, when applying the SP assay [76]. Similar results were obtained in glioma [72], ovarian [73], and pancreatic [74] cell lines. Although $\mathrm{SP}^{+}$cells were showed to be more tumorigenic when compared to $\mathrm{SP}^{-}$cells, $\mathrm{ABCG}^{+}$and $\mathrm{ABCG}^{-}$cancer cells were shown to be similar [75].

An effective method to isolate CSCs is based on their resistance to anoikis. Anoikis is a type of programmed cell death, which is activated when cells detach from the surrounding extracellular matrix. This process prevents the growth of adherent-independent cells. The resistance to this mechanism may explain cancer progression and metastasis [120]. For this reason the selection of cells resistant to anoikis may be used as an assay to obtain CSCs. Harrison et al. (2010) reported that anoikis resistant cells from breast cancer cell lines and primary human tumours were mainly $\mathrm{ESA}^{+} \mathrm{CD} 44^{+} \mathrm{CD} 24^{\text {low }}$ with self-renewal and tumorigenic properties in vitro and in vivo, therefore classified as breast CSCs [79].
Other approaches use specific culture conditions to obtain CSCs such as selection through i) chemotherapy enrichment, ii) growth of stem cells in media derived from cancer cell lines, iii) suspension culture, and iv) repetitive cycles of hypoxia and reoxygenation, among other techniques. Lu and Labhasetwar (2013) established a drug resistant MCF-7 cell line obtained after a long period of treatment with doxorubicin. The resultant cells were described to have CSC characteristics [121]. Tang and colleagues (2011) observed that methotrexateresistance osteosarcoma cells exhibited SP phenotype, expressed CSC markers and were more tumorigenic when compared to parental cells [122]. When mouse breast cancer cells were treated with pacilitaxel and epirubicin in serum-free condition and then maintained in suspension culture, they became mostly $\mathrm{CD} 44^{+} \mathrm{CD} 24^{-}$ cells together with higher tumorigenic potential [123]. Instead of long-term drug treatment, the group of Seno (2012) hypothesized that CSCs may be generated when stem cells are subjected to the influence of a tumour microenvironment. Indeed, when mouse iPSCs were maintained in media derived from a lung cancer cell line, cells with CSC-like properties appeared. Cells were described to be tumorigenic when injected in vivo, to possess the ability to self-renewal, and to express stem cell markers [83].

A variety of $3 \mathrm{D}$ in vitro sphere forming assays have been developed in order to obtain cancer stem-like cells. These in vitro assays involve mainly sphere formation in low-adherent stem cell culture conditions, a model described as tumourspheres. Often stem-like cell culture conditions include the growth of cells in low-density conditions, to avoid cell aggregation, in media supplemented with epidermal growth factor (EGF), hydrocortisone, insulin, progesterone, and/or heparin in the absence of foetal bovine serum (FBS) [124]. This system has been employed to identify cells with self-renewal and differentiation abilities and therefore to enrich CSCs, as described already for liver [125], pancreatic [126], and oesophageal [127] CSCs. This type of assay displays some disadvantages as it may require specific culture conditions and components, otherwise CSC differentiation or expansion limits may occur. Furthermore, this system does not fully reproduce the tumour from which the cells are derived, especially its structure and/ or microenvironment [46]. In addition to the identification of cancer stem-like properties, the tumourspheres were proved to be resistant to chemotherapy and tumorigenic [127]. This technique presents some disadvantages, including the low number of successfully isolated CSCs, spontaneous differentiation, and apoptosis [128, 129]. Louie et al. (2010) developed a system to enrich CSCs without genetic modification based on the hypothesis that repetitive cycles of hypoxia/reoxygenation 
may increase this cell population. When this system was applied to breast cancer cell lines, a stem-like cell population developed high tumorigenesis [130].

Strikingly, some groups have used normal somatic cells, rather than cancer cells, to generate CSCs. In a recent article by Nagata and co-workers [81] a new method was described. CSCs were originated through the overexpression of OSKM in human somatic fibroblasts. According to this method, induced pluripotent cancer stem-like cells (iCSCs) with self-renewal and pluripotency properties were established through the transduction of exogenous OSKM followed by selection, after embryoid body formation and serial transplantation in immunodeficient mice [81]. Scaffidi and Misteli (2011) generated CSCs from human fibroblasts through the expression of telomerase and oncogenic H-RasV12 mutant and concomitant inhibition of p53 and pRB. The multipotent SSEA- $1^{+}$cells generated in this process gave rise to hierarchically organized tumours composed of non-tumorigenic SSEA-1 ${ }^{-}$cells [82].

\section{Clinical applications of CSCs Introduction}

The currently held theory regarding the abundance of CSCs within a given tumour, although challenged within the studies of Quintana and others, is that is generally very low $(<0.1 \%)[47,131,132]$. Given that this population displays high resistance to selected applied therapies, a successful clinical response would come from therapies aiming to omit specifically these rare cells responsible for repopulating the tumour. By targeting the rapidly dividing cancer cells of the bulk tumour, classic chemotherapy is incapable of defeating the low-cycling CSCs. This explains cases where there is an initial visible decrease of primary tumour size as a response to treatment followed by further tumour relapse. A recent study demonstrated that CSCs can be even stimulated by chemo- or radio-therapy, and this was reflected by the higher percentage of $\mathrm{CD} 44^{+} \mathrm{CD} 24^{-}$breast CSCs after therapy [133]. It would be perhaps more effective to establish combination of therapies that can target both cancer cells and CSCs [134].

\section{Development of CSC-specific therapies}

As stated above, normal stem cells and CSCs have many properties in common. Therefore, in order for therapies to have a future translational impact, it is important that current research focuses on the identification of CSCspecific properties and of new agents that could be CSCselective. A study published in 2012 by the group of Bhatia presented a neoplastic hiPSC differentiation system for compound screening of small molecules known to induce cell differentiation [134]. The authors identified thioridazine, a clinically approved drug designed to antagonize dopamine receptors expressed on CSCs, as neoplastic cell- and CSC-specific without affecting normal stem cells, demonstrating at the same time the use of differentiation as a therapeutic strategy. In another line of studies, clinical data were recently presented at the 2015 American Society of Clinical Oncology (ASCO) annual meeting in Chicago regarding the development of two novel compounds, BBI608 and BBI503, orallyadministered, which are designed to target CSC pathways in multiple tumour types. BBI608 targets STAT3, leading to inhibition of the critical genes for maintaining cancer stemness. It was also shown to enhance antitumour activity when administered with classic chemotherapy in gastric and colorectal cancer. BBI503 inhibits Nanog and other cancer stem cell pathways by targeting kinases, and showed encouraging early signs of anticancer activity for patients with advanced colorectal cancer [135]. To date, many CSC-limited therapies based on identified CSC-specific properties have been proposed, many of which hold promise for clinical therapy. Table 2 categorizes these CSC-specific therapies.

\section{Therapies targeting the CSC microenvironment/niche}

The CSC microenvironment is now considered a hot target field in CSC therapy. The idea would be to simply disturb the supportive microenvironment that can feed and support the CSCs population. Niches are the most widely studied microenvironments, defined by a variety of cell types such as cancer associated fibroblasts (CAFs), tumour associated macrophages (TAMs), tumour endothelial cells (TECs), mesenchymal stem cells, immune and endothelial cells lining across the tumour vasculature, cell-cell contacts, extracellular matrix (ECM), and soluble factors such as growth factors and cytokines [136]. Although normal and tumour niches differ in many aspects, manipulation of the conditions of the tumour/metastatic niche may modulate the cancer stem cell frequency, survival and potency. Stromal incompatibility can influence the number of CSCs in human tumours by dramatically affecting the survival of the engrafted human cells within the host, which may be mitigated when humanized mouse models (NSG) are used. Kuperwasser and colleagues (2004), in an effort to reconstruct the human mammary gland within mice, showed that both stromal and epithelial components are necessary for the development of the xenografts in vivo, whereas genetic manipulation of the stromal cells prior to transplantation resulted in the growth of neoplasias. These mouse models, which manage to recapitulate the biological features of patients' samples, not only provide a unique way to study the steps of cancer pathogenesis in vivo, but also hold promise for individualized cancer therapy, allowing the prediction of patients' response to clinically tested anticancer regimens [49]. 
Table 2 Selected clinical therapeutic agents in current cancer stem cell drug treatment

\begin{tabular}{|c|c|c|c|}
\hline Target & Name of drug (synonyms) & Mechanism of action & Ref.(s) \\
\hline \multirow{27}{*}{$\begin{array}{l}\text { Microenviroment/ } \\
\text { Niche }\end{array}$} & Anti-CD44 monoclonal Abs & CD44 activation & [249] \\
\hline & Oblimersen sodium (G3139) & $\mathrm{Bcl} 2$ antisense oligonucleotyde & [250] \\
\hline & AT-101 (gossypol) & BCl2, Mcl1 inhibitor & {$[251,252]$} \\
\hline & ABT-263/ABT-737 & Pan $\mathrm{Bcl} 2$ inhibitor & [253] \\
\hline & Obatoclax (GX15-070) & & [254] \\
\hline & Sabutoclax (Bl-97C1) & & [255] \\
\hline & Anti-integrin alfa 6 monoclonal Abs & Block integrin alfa 6 binding & [256] \\
\hline & GLPG0187 & Integrin alfa peptide antagonist & [257] \\
\hline & EMD 121974 (Cilengitide) & Integrin alfa beta peptide antagonist & {$[258,259]$} \\
\hline & Volociximab & $\begin{array}{l}\text { Monoclonal antibody targeting integrin } \\
\text { alfa beta }\end{array}$ & [260] \\
\hline & ATN-161 & Integrin alfa beta peptide antagonist & [261] \\
\hline & Pepducins & CXCR4 antagonist & [262] \\
\hline & Plerixafor (AMD3100) & & [263] \\
\hline & Neutralizing ab & CXCR4 blocker & [264] \\
\hline & Bevacizumab (Avastin) & VEGF-ANEGFR blocker & {$[151,265]$} \\
\hline & Cediranib/AZD2171 & Tyrosine kinase inhibitor VEGFR2 & {$[152,266]$} \\
\hline & EphA3 monoclonal Abs & EphA3 blockers & $\begin{array}{l}\text { Clinical trial phase I by KloBios } \\
\text { Pharmaceuticals }\end{array}$ \\
\hline & Systemic infusion of enzyme PEGPH20 & HA inhibitor & [156] \\
\hline & $\begin{array}{l}\text { Anthracyclines, EGFR inhibitors, cardiac } \\
\text { glycosides, histone deacetylases, HSP90 } \\
\text { inhibitors, microtubule targeting agents, } \\
\text { proteasome inhibitors, topoisomerase } \\
\text { I inhibitors }\end{array}$ & HIF-1 inhibitors & Reviewed in [158] \\
\hline & DNA vaccines & $\begin{array}{l}\text { Legumain, Fra-1, Stat3, FAP, HER-2 } \\
\text { (CAFs-TAMs) }\end{array}$ & Reviewed in [138] \\
\hline & Monoclonal Ab Sibrotozumab & FAP & Clinical trial phase I [267]; [139] \\
\hline & PAl-1 & UPA/UPAR inhibitors & Reviewed in [137] \\
\hline & Radioactive labeled Ab, siRNA & Tenascin-C & Reviewed in [137] \\
\hline & Monoclonal Ab 81C6 & & Clinical trial phase II [267]; [147] \\
\hline & NK4, anti-HGF mAbs & HGF/Met & {$[142,143]$} \\
\hline & 5-Aza-2'-deoxycytidine & DNMT1 & [140] \\
\hline & MMPs inhibitors & MMPs & {$[141,268]$} \\
\hline \multirow[t]{9}{*}{$\begin{array}{l}\text { Wnt/ßcatenin } \\
\text { pathway }\end{array}$} & $\begin{array}{l}\text { Anti-Frizzled (Fzd7) monoclonal } \\
\text { antibodies (OMP-18R5) }\end{array}$ & $\begin{array}{l}\text { Block formation of active receptor } \\
\text { signalling complex; binds } 5 \text { Fizzled } \\
\text { receptors }\end{array}$ & $\begin{array}{l}\text { Clinical trial phase I by OncoMed; [159, } \\
267]\end{array}$ \\
\hline & $\begin{array}{l}\text { Truncated Fizzled 8-Fc fusion } \\
\text { protein (OMP-54 F28) }\end{array}$ & Fzd8-Fc selectively binds Wnt ligands & $\begin{array}{l}\text { Clinical trial phase I by OncoMed in } \\
\text { collaboration with Bayer Pharma AG }\end{array}$ \\
\hline & NSAIDs & COX mechanisms & {$[269,270]$} \\
\hline & IWP2 & o-acetyltransferase inhibitor & {$[271]$} \\
\hline & XAV939 & Tankyrase inhibitor & {$[272]$} \\
\hline & PKF115-584 & TCF/ßcatenin inhibitor & {$[273]$} \\
\hline & CGP049090 & & \\
\hline & IWR & Axin stabilizer & {$[271]$} \\
\hline & ICG-001 & CREB/ßcatenin interaction inhibitor & {$[274]$} \\
\hline \multirow[t]{2}{*}{ Hedgehog pathway } & GANT-61 & Gli DNA binding inhibitor & [173] \\
\hline & Arsenic trioxide & & {$[174]$} \\
\hline
\end{tabular}


Table 2 Selected clinical therapeutic agents in current cancer stem cell drug treatment (Continued)

\begin{tabular}{|c|c|c|c|}
\hline & BMS-833923 (XL139) & SMO inhibitor & {$[267]$} \\
\hline & LDE-225 & & \\
\hline & LEQ506 & & \\
\hline & PF-04449913 & & \\
\hline & TAK-441 & & \\
\hline & Cyclopamine and based compounds & & {$[170]$} \\
\hline & Vismodegib (GDC-0049) & & {$[275]$} \\
\hline \multirow[t]{27}{*}{ mTOR/PI3K/Akt } & Perifosine (krx-0401, d-21266) & Akt inhibitor & {$[276]$} \\
\hline & MK-2206 & & {$[277]$} \\
\hline & GSK690693 & & [278] \\
\hline & GSK2141795 & & [279] \\
\hline & LY2780301 & & {$[280]$} \\
\hline & Rapamycin & mTORC1 inhibitor & [281] \\
\hline & Temisirolimus (CCl-779) & & [282] \\
\hline & Everolimus (SDZ RAD) & & [283] \\
\hline & Ridaforolimus (AP23573, MK-8669) & & {$[284]$} \\
\hline & OSI-027 & mTORC1/2 inhibitor & [285] \\
\hline & PP242 & & [286] \\
\hline & PP30 & & \\
\hline & WAY-600 & & [179] \\
\hline & WYE-687 & & \\
\hline & WYE-354 & & \\
\hline & AZD8055 & & {$[287]$} \\
\hline & INK128 & & [288] \\
\hline & NVP-BKM120 & PI3K inhibitor & [289] \\
\hline & PX-866 & & [290] \\
\hline & GDC-0941 & & [291] \\
\hline & CAL-101 (GS-1101) & & [292] \\
\hline & SF1126 & PI3K \& mTOR inhibitor & [293] \\
\hline & NVP-BEZ235 & & [294] \\
\hline & XL765 & & [295] \\
\hline & GDC-0980 & & [296] \\
\hline & $\mathrm{Pl}-103$ & & [297] \\
\hline & Metformin & $\begin{array}{l}\text { Inhibition of mTOR activation } \\
\text { through AMPK }\end{array}$ & [181] \\
\hline \multirow[t]{8}{*}{ Notch pathway } & $\begin{array}{l}\text { Anti-Notch } 2 \text { and } 3 \text { monoclonal } \\
\text { Abs (OMP-595R) }\end{array}$ & Block cleavage of Notch receptor & Clinical trial phase I by OncoMed \\
\hline & Anti-Notch 1 and 2 monoclonal Abs & & [298] \\
\hline & Anti-Notch 3 monoclonal Abs & & [299] \\
\hline & Anti-DLL4 (demcizumab) & Block binding of DLLL4 to & Clinical trial phase I by OncoMed \\
\hline & $\begin{array}{l}\text { Anti-DLL4 monoclonal Abs } \\
\text { (OMP-21 M18, REGN421) }\end{array}$ & Notch receptor & {$[160,267]$} \\
\hline & DAPT & Gamma-secretase inhibitor & {$[300]$} \\
\hline & MRK-003 & & {$[301]$} \\
\hline & LY450139 & & {$[302]$} \\
\hline Telomerase & Imetelstat/GRN-163 L & Telomerase inhibitor & \\
\hline
\end{tabular}


Table 2 Selected clinical therapeutic agents in current cancer stem cell drug treatment (Continued)

\begin{tabular}{|c|c|c|c|}
\hline & & & $\begin{array}{l}\text { Clinical trial phase II by Geron } \\
\text { Corporation; [216] }\end{array}$ \\
\hline & GRN-163 & Antagonist of telomerase template & {$[303]$} \\
\hline \multirow[t]{2}{*}{ Drug efflux } & PSC-833 & $A B C B 1$ inhibitor & {$[304]$} \\
\hline & YHO-13351 & ABCG2 inhibitor & {$[305]$} \\
\hline \multirow{4}{*}{$\begin{array}{l}\text { Redox balance and } \\
\text { metabolism }\end{array}$} & Genipin & Suppression of UPC2 & {$[228]$} \\
\hline & Phytochemicals & Redox system & {$[225,226]$} \\
\hline & Indo-3-carbinol (I3C) & Redox system (stimulates BRCA1) & \\
\hline & Genistein & $\begin{array}{l}\text { Redox system (ROS scavenger, inhibitor } \\
\text { of NFkB, Akt, PTK) }\end{array}$ & {$[227]$} \\
\hline \multirow[t]{9}{*}{$\begin{array}{l}\text { CSC immunogenic } \\
\text { responses }\end{array}$} & CD133 peptide, ICT-121 & Dendritic cell-based vaccine & $\begin{array}{l}\text { Clinical trial phase I by ImmunoCellular } \\
\text { Therapeutics }\end{array}$ \\
\hline & Peptide vaccine (SL401 and SL701) & Interleukin-3 receptor & $\begin{array}{l}\text { Clinical trial phase I and II completed by } \\
\text { Stemline Therapeutics }\end{array}$ \\
\hline & VS6063 & Focal adhesion kinase (inhibitor) & $\begin{array}{l}\text { Clinical trial phase I completed by } \\
\text { Verastem and Pfeizer }\end{array}$ \\
\hline & Ipilimumab & CTLA-4 blockers & $\begin{array}{l}\text { Clinical trial phase III by BMS/Medarex; } \\
\text { [306] }\end{array}$ \\
\hline & TGN1412 & CD28 agonist & Clinical trial phase I [267]; [307] \\
\hline & MDX-1106 & PD-1 antagonist & Clinical trial phase I [267]; [308] \\
\hline & Celebrex, Rofecoxib & COX2 inhibitors & Reviewed in [209] \\
\hline & $\begin{array}{l}\text { CXCR1 blocking Abs or small } \\
\text { molecule repertaxin }\end{array}$ & IL-8/CXCR1 inhibitor & [210] \\
\hline & $\begin{array}{l}\text { TGF- } \beta \text { type II receptor antibody } \\
\text { or SMAD4 siRNA }\end{array}$ & TGF- $\beta / S M A D ~ 4$ & {$[211]$} \\
\hline \multirow[t]{2}{*}{ Stemness } & BB|608 & STAT3 inhibitor & Clinical trial phase III [135] \\
\hline & BBI503 & Nanog inhibitor & \\
\hline \multirow{3}{*}{$\begin{array}{l}\text { miRNA based } \\
\text { therapies }\end{array}$} & let-7 anti-sense oligos & H-RAS and HMGA2 & [197] \\
\hline & miR200c & Bmi-1, ZEB1 & [199-201] \\
\hline & miR-34a & CD44 activation & [202] \\
\hline
\end{tabular}

CAFs, TECs, and TAMs are fundamental components of tumour microenvironment, whose role is critical in carcinogenesis and for this reason have attracted a lot of attention as potential targets of tumour microenvironment (reviewed in [137]). CAFs overexpress specific therapy targets such as legumain, an asparaginyl endopeptidase, proto-oncogene Fra-1, transcription factor Stat3, fibroblast activation protein (FAP) as well as HER-2. The development of DNA vaccines directed against some of these targets resulted in the elimination of tumour growth, progression, metastasis and recurrence in mouse tumour models (reviewed in [138]). FAP, a protein that may play a role in the differentiation of fibroblasts to myofibroblasts, can be inhibited via a monoclonal antibody, sibrotuzumab has shown to be promising in early clinical trials [139]. Another approach for CAF-targeted therapy would be the use of drugs that inhibit differentiation of stromal cells into activated CAFs, such as the use of the DNA demethylating agent $5 \mathrm{aza}-\mathrm{dC}$ (5-aza-2'-deoxycytidine) to inhibit myofibroblast differentiation from hepatic stellate cells
[140]. In addition, certain epithelial cell derived matrix metalloproteinases (MMPs) (i.e. MMP 7, 9, 2 and 3) may play a role in myofibroblast differentiation and in ECM remodelling. MMPs can be targeted in therapy using MMP inhibitors like TIMP-2 [141]. A third approach would be stroma-directed therapies against growth factors, secreted by activated CAFs, which act on epithelial transformation and enhance invasiveness. For example, the hepatocyte growth factor (HGF/Met) pathway has been used as a target in early pre-clinical studies using NK4, a competitive antagonist of Met and anti-HGF monoclonal antibodies [142, 143]. Another CAF-derived factor, the urokinase plasminogen activator (UPA) and its receptor (UPAR) and their mediated signalling have been implicated in tumour cell invasion, survival, and metastasis in a variety of cancers. Inhibitors of uPA and radioactive labelled PAI-1 have shown efficacy in inhibiting tumour growth and invasion in pre-clinical studies of pancreatic and prostate cancers $[144,145]$ (reviewed in [137]). Tenascin-C, another target of therapy abundantly expressed in CAFs, binds to cell 
surface receptors and ECM components and has been known to promote colon cancer metastasis in response to TGF- $\beta$ signalling [146]. Tenascin- $C$ inhibitors and the monoclonal antibody 81C6 have been shown to be effective in early clinical trials in astrocytomas and NonHodgkin's lymphoma [137] and in brain tumours [147], respectively. The CAFs-related connective tissue growth factor (CTGF) holds a therapeutic promise. Aikawa et al. (2006) developed a fully humanized CTGF-specific monoclonal antibody, FG-3019, as a novel therapeutic approach for pancreatic ductal adenocarcinoma. FG-3019 decreased the volume of intra-pancreatic tumour and attenuated its metastatic potential [148].

The prevention of the growing vascularisation in the tumour can be used as a CSC-target therapy. Vascular endothelial growth factor (VEGF), a molecule that directly supports the development of local vasculature, is the target of bevacizumab [149]. When glioma and medulloblastoma were treated with this inhibitor, a depletion of CSCs was observed, demonstrating that VEGF is a relevant target for CSCs [150]. Promising results of anti-angiogenesis therapy have been reported in clinical trials for bevacizumab [151] or cediranib (AZD2171, a VEGFR inhibitor) [152]. Interactions with the stromal microenvironment can alter the survival pathways that are activated in CSCs. One example might be the culture of pro-survival proteins, like $\mathrm{Bcl}-2$ and $\mathrm{Bcl}-\mathrm{X}_{\mathrm{L}}$ with $\mathrm{CD}_{4} 4^{+}$leukaemia CSCs, thus diminishing apoptosis after chemotherapy [153]. In addition to VEGF inhibitors, a high number of Bcl-2 family inhibitors are currently in preclinical and clinical drug development [154].

An anti-EphA3 antibody, currently in phase I trial, offers another potential therapy acting on the microenvironment. EphA3 was found to be expressed in the preB leukaemia cell line and in a subset of samples from patients with leukaemia [155]. Although no direct link was found between EphA3 expression and LSCs, studies have shown that anti-EphA3 may act against CSCs, since its incubation with preB leukaemia cells leads to the loss of the CSC's in vitro ability to form colonies. In a study by Provenzano et al. (2012), when an enzyme (PEGPH20) targeting hyaluronic acid (HA) is systemically delivered with standard chemotherapy it can permanently remodel the tumour microenvironment and achieve better antitumour responses, resulting in a near doubling of the overall survival [156]. A detailed list of drugs targeting various components of the niche is listed in Table 2.

The hypoxic niche is another area of significant interest. The slow proliferation or quiescence that normal stem cells exhibit under low $\mathrm{O}_{2}$ conditions resembles that of cancer stem cells' genetic-epigenetic adaptation to the hypoxic conditions in the centre of a poorly vascularised and oxygenated tumour. The brain CSCs, which reside in low oxygenated perivascular niches inside the bulk tumour, were shown to be specifically increased by hypoxia [149]. A hypoxic niche for glioma cells was described by Jeremy Rich's laboratory showing that hypoxic conditions resulted in reprogramming of $\mathrm{CD} 133^{-}$cells to $\mathrm{CD} 133^{+}$with enhanced CSC-phenotype [157]. A major mechanism mediating the adaptation to hypoxia is the activity of transcription factor HIF-1. Existing pharmacological data demonstrate the anticancer effects of HIF-1 inhibitors and drug-efflux pump inhibitors, as monotherapy and/or as sensitizers to chemotherapy in mouse models of human cancer [158].

\section{Therapies targeting central signalling pathways of CSC survival}

Other drug candidates may target the Wnt, mTOR/ PI3K/Akt, or Notch pathways, involved in both CSC and adult stem cell signalling $[159,160]$. The Wnt pathway plays a central role in a whole spectrum of different developmental processes, including cell proliferation and migration, being crucial in cell fate and tissue patterning $[161,162]$. It is already known that the Wnt pathway is involved in the self-renewal of both normal and cancer stem cells. Indeed, aberrant Wnt signalling was observed in the CSC population from many tumour types [161]. The high number of Wnt isoforms and the complicated mechanism of the Wnt pathway may explain why most of its inhibitors are still in the preclinical stage. Extirpation of CSCs by Wnt-selective drugs without depleting the normal haematopoietic stem cells (HSCs) in $\mathrm{G}_{1}$ phase, cells depending on the Wnt pathway, might be limited. Instead, the non-steroid anti-inflammatory drugs (NSAIDs), indomethacin or sulindrac, have been proved to act on the Wnt/ $\beta$ catenin pathway $[163,164]$, as have the second generation cyclooxygenase 2 (COX2) inhibitors like celecoxib [165]. Lately, a downregulation of the Wnt inhibitory factor 1 (WIF1) as a widespread event in salivary gland carcinoma ex-pleomorphic adenoma (CaExPA), has been described [163, 166]. WIF1 downregulation occurs in the CaExPA precursor lesion pleomorphic adenoma (PA) and indicates a higher risk of progression from benign to malignant tumour [166]. Most importantly, WIF1 significantly diminished the number of salivary gland CSCs and the anchorageindependent cell growth. Consistent with this observation, WIF1 caused a reduction of the expression of pluripotency and stemness markers as well as the adult stem cell self-renewal and multi-lineage differentiation markers WNT3A, TCF4, c-Kit, and Myb [166]. Detailed names and corresponding references of candidate drugs targeting the Wnt pathway are listed in Table 2.

The Hedgehog $(\mathrm{HH})$ pathway is involved in the maintenance and regeneration of adult tissues, through the regulation of adult stem cells, as well as in cancer development through the regulation of CSCs [167]. Currently 
three mammalian $\mathrm{HH}$ ligands have been identified, of which Sonic $\mathrm{HH}(\mathrm{SHH})$ is the best described and studied. In the absence of $\mathrm{HH}$ ligand, its receptor called Patched (Ptch) represses Smoothened (SMO). Binding of $\mathrm{HH}$ removes this repression, allowing SMO to activate Gli family of transcription factors and other targets [168].

Although the $\mathrm{HH}$ pathway can be activated at several different points, most drugs target the SMO transmembrane protein. The first inhibitor to be identified was cyclopamine, which directly binds to SMO to efficiently block the $\mathrm{HH}$ pathway and decrease CSCs number in preclinical models $[169,170]$. Unfortunately, the use of cyclopamine is limited due to its low oral bioavailability and pharmacokinetics [171]. The first clinically approved antagonist of $\mathrm{HH}$ is vismodegib (GDC-0049). Several more small molecules are currently being clinically tested like PF-04449913 or TAK-441 among others (Table 2). The HH pathway can also be a target by upstream ligands or by downstream effectors. Antibodies targeting $\mathrm{SHH}$ have been shown to inhibit the clonogenic potential of CSCs [172]. Inhibitors of Gli transcription factors, such as the Gli DNA binding inhibitor GANT-61 [173] and arsenic trioxide [174], may significantly reduce self-renewal in tumours with mutations that are located downstream of SMO, or which simply acquire resistance to SMO-targeted molecules.

The mTOR/PI3K/Akt pathway is another known CSC therapeutic target as it has been shown to be especially involved in the generation and survival of leukaemia [175]. Many different mTOR inhibitors were already developed and tested, including rapamycin itself and rapamycinrelated drugs (e.g. CCI-779 and RAD001). Although these molecules were shown to inhibit CSC self-renewal [176], clinical use had limited success [177, 178]. Meanwhile, novel ATP-competitive inhibitors that can target both mTORC1 and mTORC2 complexes have been tested [179]. Alternatives are a combination of different mTOR/ PI3K/Akt inhibitors that have been proven to be effective in CSCs and some of them are currently in phase 1 of clinical trials. Gemcitabine, a nucleoside analogue used in chemotherapy, when combined with rapamycin significantly reduced the percentage of pancreatic CSCs in vitro obtained from primary patient samples [180]. An alternative therapeutic candidate of mTOR inhibitors is metformin, a well-known drug for the treatment of type 2 diabetes. Metformin blocks mTOR through AMPK activation, important in protein synthesis, cell cycle progression, and cell survival [181]. A combination of metformin with chemotherapy displays prolongation of survival of breast, lung and prostate cancers [182, 183]. Shank and colleagues (2012) observed an inhibition of ovarian CSCs growth in vitro caused by metformin, dissimilar to what was observed in vivo. However, when combined with cisplatin, a chemotherapeutic drug tested in different types of cancer, a restriction of the tumour growth in vivo was observed [184]. Detailed names and corresponding references of candidate drugs targeting the mTOR/PI3K/Akt pathway are listed in Table 2 .

Notch signalling, another stem cell-supporting pathway, is activated in many human cancer types and its deregulation is related with this disease. The Notch pathway has been reported to play an important role in the regulation of asymmetric cell fate decisions in human mammary stem cells [185]. Abnormal activation of the Notch pathway has been observed in CSCs from some tumours, mostly related to self-renewal maintenance and resistance to therapy observed in these cells [186]. Therefore, inhibition of the Notch signalling pathway could be a therapeutic target for the elimination of the CSC subpopulation [187]. Preclinical analysis in leukaemia, medulloblastoma and breast cancer with the gamma-secretase inhibitors DAPT [79, 188], GSI-18 [189, 190], and MRK-003 [191], showed selective targeting of CSCs and reduced tumour sizes (Table 2). Moreover, the Notch pathway could be a direct target of miRNAs closely related to invasion and acquisition of stem cell like properties by tumour cells [192]. More drugs targeting different components of the Notch pathway are listed in Table 2.

\section{Therapies targeting CSC-miRNAs}

miRNAs are relatively small noncoding RNA molecules that serve as transcriptional and post-transcriptional repressors through the binding to their mRNA targets [193]. Taking into account that different types of cancer have specific profiles of miRNA expression reminiscent of their stem cell of origin [194], the application of miRNA-based tools in cancer therapy has lately attracted a lot of interest [193]. miRNAs appear attractive therapeutic targets in cancer as they may affect the expression of multiple genes in different developmental contexts, including regulation of critical stem cell features as well as metastasis, EMT, and cell division. For these reasons, many miRNAs have been successfully targeted in vivo in mouse models with the use of specific inhibitors called antagomiRs [195] or have been proposed as targets in exosome biology, by either targeting the release of miRNAs from exosomes, or by using these "bioactive vesicles" for therapeutic delivery (reviewed in [196]).

In a study on breast cancer cell lines and human primary cancer cells let-7a miRNA, negative regulator of stemness, was found significantly decreased in breast CSCs and increased with differentiation [197]. Re-expression of let-7 miRNA in CSCs using a lentivirus construct causes a reduction of the CSC proliferation and mammosphere formation. Moreover it also negatively influenced the ability of CSCs to form tumours and metastasis in mice [197]. In another study of 2009, 37 miRNAs were described as being 
up- or down-regulated in $\mathrm{CD} 44^{+} \mathrm{CD} 24^{-}$breast CSCs when compared to non-tumorigenic cells [198]. Shimono and coworkers focused mostly on BMI1 since it is known to regulate normal and CSC activity [199, 200]. Exogenous miR200c was found to promote reduction of BMI1 protein levels and embryonal carcinoma cells growth in vitro and in vivo in NOD/SCID mice $[199,200]$. In normal mouse breast stem cells expression of miR-200c repressed outgrowth formation in the mammary fat pad assay [200], while miR-200c expression in human breast CSCs blocked tumour initiation in NOD/SCID mice [197, 201]. miR-34abased therapies are emerging as novel modes of therapeutic interventions. Systemic delivery of miR-34a, which is known to target CD44 and is usually repressed in prostate cancer, inhibited metastasis of prostate cancer cells and prolonged survival of mice [202].

\section{Therapies targeting CSC-immunogenic responses}

Immune tolerance is an important property of a growing tumour. Complexed immunogenic reactions taking place within the tumour microenvironment are responsible not only for tumour's survival against the immune system but also for the enhancement of its stemness and migration properties. In a study of Giannoni et al. (2010), IL-6 was shown to activate the CAFs, which in turn induced EMT and stemness of prostate cancer cells [203]. In support of this, Iliopoulos et al. (2011) identified IL-6 as the mediator responsible for conversion of non-stem cancer cells into CSCs in breast and prostate cancer [204]. Therapyinduced changes in the tumour stroma play a critical role in determining phenotypic plasticity and may be responsible for pro-malignant phenotype acquired by the surrounding CAFs [205]. Such events give rise to a proinflammatory microenvironment characterized by increased expression of TNF $\alpha$, pro-inflammatory cytokines, and INF $\gamma$, which finally induce STAT3/NFkB signaling responsible to promote self-renewal in ESCs [206] but also to mediate resistance to therapy [207]. In another study, it was reported that mesenchymal cells in breast cancer support CSCs through a signalling loop dependent on IL-6 and CXCL7 [208].

For these reasons, many pharmaceutical companies today aim in the targeting of CSC subpopulation based on selected immunogenic responses. Most promising from current clinical trials are candidates that are related with CSC-associated proteins used as antigens to elicit an immune response against CSCs (Table 2). Other drugs, such PD-1 and COX2 inhibitors and CD28 agonists, have been proposed as promising anti-cancer therapies Some of them, like celecoxib and rofecoxib, have both been tested in phase II clinical trials in combination with chemotherapeutic agents in patients with NSCLC, and pancreatic, breast, and colorectal cancers and, for the most part, have shown additional clinical benefit beyond that observed with chemotherapy alone (reviewed in [209]). In another study, Ginestier et al. (2010) developed a strategy to deplete selectively breast CSCs in preclinical models through blockade of the IL-8 receptor CXCR1 using either a CXCR1-specific blocking antibody or repertaxin, a small-molecule CXCR1 inhibitor [210]. Blockade of TGF- $\beta /$ SMAD signaling pathway by the TGF- $\beta$ type II receptor antibody or SMAD4 siRNA repressed enrichment of CSCs in the triple negative breast cancer cell model [211]. Additional candidate drugs targeting immunogenic responses of CSCs have been proposed and some of them have reached the clinical phase (Table 2).

\section{Therapies targeting telomeres and telomerases}

Another example of CSC-specific targets is telomeres and telomerases. Regions of repetitive nucleotide sequences called telomeres protect the end of the chromosomes from being recognized as double-strand breaks by the DNA repair system [212]. Classic stem cells display constitutive activity of telomerase, an enzyme that adds DNA sequence repeats to the telomere regions, and its presence in cancer cells can be a reflection of an origin of those cancers from stem/progenitor cells and the imposition of maturation arrest [213]. Compared to normal stem cells, cancer stem cells express higher levels of telomerase [214]. Based on that, telomerase could be a relevant target in CSCs without destroying healthy stem cells. The most common approach to target telomerase activity is immunotherapy and the use of oligonucleotide-based hTERT inhibitors [215], both listed in Table 2. Widely studied telomerase inhibitors are GRN163 and a more potent lipid attached derivative, GRN163L (imetelstat) [216]. The telomerase specific drugs lead to the reduction in the selfrenewal capacity of treated CSCs as assessed by in vitro sphere formation [217] (Table 2). One telomerase related drug imetelstat, was shown to block replication of glioblastoma CSCs and to decrease tumour growth [218]. Furthermore, telomerase inhibitors are expected to target also the bulk of the tumour. Treatment of glioma, neuroblastoma, lung and prostate CSCs with imetelstat induces reduction in the self-renewal capacity of these cells as assessed by the in vitro sphere formation. Another finding was that this drug displays effective properties against xenograft tumours and reduced the number of CSCs remaining in treated tumours [218].

\section{Therapies targeting CSC redox balance and metabolism}

Another feature that characterizes CSCs and has been under investigation for clinical targeting is the redox balance. Oxidative stress refers to a condition of the cell characterized by an excess of reactive oxygen species (ROS) [28]. ROS, such as superoxide, hydrogen peroxide, and peroxynitrite, are physiological byproducts of mammalian 
metabolism, and in excess may cause cell damage by oxidation and nitration of macromolecules, such as DNA, RNA, proteins, and lipids [219]. A cell generally undergoes apoptosis when ROS levels are high or goes into senescence at sublethal levels [220]. In turn, ROS may play a role in cell proliferation, differentiation, and apoptosis through the control of signalling pathways [221].

The subsistence of the redox status is important for normal stem cells to avoid cellular differentiation, to maintain long-term self-renewal and to decrease the accumulation of DNA damage [28, 222]. This is indicated by the general low levels of ROS in normal stem cells compared to their differentiated progeny, as shown in normal HSCs and progenitors, central nervous system stem cells and normal breast stem cells [223, 224]. The resistance to oxidative stress is regulated by the ROS scavenging system that is upregulated in these cells. Cellular redox status is maintained by several intracellular redox-regulating molecules, including thioredoxins (TRX), and glutathione (GSH)/glutaredoxin (GRX). Molecules or enzymes that can destabilize the redox status of cancer cells will be beneficial for actually killing them. In fact, the combination of chemotherapy with cellular redox system modifiers has shown promising results in clinical trials. For example targeting redox system with phytochemicals, natural substances derived from vegetables, fruits and spices, is another method described as being capable of intervening in carcinogenesis, which has already reached clinical trials both in combination with, and without, conventional chemotherapy [223]. In another study, a phytochemical from cruciferous vegetables, the indole-3-carbinol (I3C), was associated with a reduced risk of several tumour types, such as breast and prostate cancers. In the acidic environment of the stomach, I3C undergoes hydrolysis to a number of products, including a dimeric product, 3,3'-diindolylmethane (DIM). Both of these phytochemicals stimulate BRCA1 in breast and prostate cancer cells and have been shown to protect cells against oxidative stress mediated by $\mathrm{H}_{2} \mathrm{O}_{2}$ and $\gamma$-radiation [225, 226]. Another natural substance, genistein (4,5,7-trihydroxyisoflavone), which was identified as the predominant isoflavone in soybean enriched foods, has been shown to inhibit prostate carcinogenesis in animal models. Genistein has antioxidant effects and protects cells against ROS by scavenging free radicals, inhibiting the expression of stress-response related genes [226]. Furthermore, genistein is a powerful inhibitor of NFkB, Akt and PTK signalling pathways, all of which are important for cell survival [227].

Moreover, since mitochondria are the main source of ROS, its limitation can be achieved by switching metabolic pathways from oxidative phosphorylation to aerobic glycolysis, a phenomenon known as the "Warburg effect", which is characteristic of normal and CSCs. The mitochondrial uncoupling enzymes UCP2 are considered responsible for this metabolic change and this is the main reason why they are in the focus of drug development. Suppression of UCP2 by genipin, a plant derived small molecule, was shown to suppress tumorigenic properties of breast cancer cells, mediated by a decrease of ROS and downregulation of UCP2 [228].

\section{Biomarker discovery and cancer clinical diagnostics}

In order to reduce the rate of adverse clinical outcome among patients, it is very important to detect cancer in early stages as well as to identify which patients are more likely to benefit from available therapies. In this way, identification of biomarkers and their application in the screening of cancer are of enormous importance as they would allow proper detection and prognosis of cancer [229]. Biomarkers, molecules found in tissues or fluids within the body of an individual and related with a disease [230], can be either DNA, RNA, miRNA, epigenetic modifications or protein expression [51]. Biomarkers may be used to detect cancer, risk assessment, distinction between benign and malignant forms of cancer, disease status, response to therapy, tumour recurrence and many other applications [231]. Kim et al. (2013) developed an in vivo model of pancreatic cancer at an early stage of the disease that can be advantageous in the identification of biomarkers related with this phase of the disease and applicable to disease monitoring after therapy [69]. Three month old teratomas, generated from the injection of reprogrammed human pancreatic ductal adenocarcinoma (PDAC) cells into immunodeficient mice, exhibited pancreatic intraepithelial neoplasia (PanIN) structures and marker expression related to the early stage of the disease. When teratomas were observed 6-9 months after injection, a progression to invasive stage of human pancreatic cancer was detected. Indeed, proteins collected from the serum-free media and analysed by nanoLC/MS/MS enabled the identification of secreted or released proteins associated with the activation of HNF4 $\alpha$ specific to the late PanIN stage [69]. This discovery can be used as a tool in the diagnostics and disease monitoring after therapy of pancreatic cancer.

Recent technological advances have allowed the possibility to analyse the characteristics of circulating exosomes and microvesicles secreted by CSCs for cancer detection and monitoring. Exosomes, small endocytic membrane-derived vesicles important for cell homeostasis and cell-to-cell communication present in most bodily fluids, can harbour a variety of proteins, nucleic acids, and lipids. Exosomes can merge with and release their contents in recipient cells and can exhibit a broad range of functions, can mediate adaptive immune responses to pathogens and tumours, promote tumorigenesis, angiogenesis, 
and metastasis, and can determine response to therapy by transferring oncogenes and onco-miRNAs between cancer cells or between the tumour and its stromal environment. Exosomes are very stable and due to their phospholipid bilayer protect their contents from degradation by nucleases and proteases. Consequently, biomarkers at a relatively low expression are much easier to be detected through isolating exosomes. For instance, some biomarkers such as PCA3 and TMPRSS 2 are mRNAs not easily detected in body fluids, but appear in exosomes in prostate cancer [232].

$\mathrm{CD}^{+} 3^{+}$exosomes were significantly increased in plasma of melanoma patients compared to healthy controls [233], while in a comparative analysis, CD63 was found enriched in exosomes derived from malignant cancer cells compared to those derived from non-cancer cells [234]. In another study, glioblastoma-specific epidermal growth factor receptor vIII (EGFRvIII) was found in serum exosomes from a significant proportion of patients, whereas EGFR, EGFRvIII, and TGF- $\beta$ were found in serum exosomes from patients with brain tumours, suggesting that they all might provide diagnostic information for glioblastomas and brain tumours respectively $[235,236]$. Since 2009, when it was reported that miRNAs, previously demonstrated as diagnostic markers for ovarian cancer, were found at similar levels in biopsy specimens of ovarian cancer and serum exosomes isolated from the same ovarian cancer patients, many cases of exosomal miRNAs have been proposed for cancer diagnostics. Brase and coworkers showed that serum levels of miR-141 and miR-375 correlate with tumour progression in prostate cancer [237]. Moreover, the exosomal miR-21 level was found elevated in serum from patients with esophageal squamous cell cancer (ESCC) versus serum from patients who have benign tumors without systemic inflammation [238]. Interestingly, Takeshita and colleagues reported that serum-derived exosomal miRNA-1246 was a good biomarker that significantly correlated with the metastasis stage and was found to be a strong independent risk factor for poor survival [239]. In a study of stage I involving PDAC patients, higher levels of exosome-resident macrophage migration inhibitory factor (MIF) were found to predict an increased risk of the eventual development of liver metastasis [240].

In contrast to exosomes, which originate from endosomes, microvesicles are fragments that derive directly from the plasma membrane, with a size range from $100 \mathrm{~nm}$ to $1 \mu \mathrm{m}$. The group of Camussi demonstrated recently that microvesicles derived from CSCs can induce angiogenesis and lung metastasis in vivo [241]. The group of researchers isolated $\mathrm{CD} 105^{+}$cells from human renal carcinoma and showed they possess CSC characteristics like expression of stem cell markers, formation of spheres in vitro, and ability to form tumours in vivo.
The CSC-derived microvesicles were $\mathrm{CD} 105^{+}$and contained mRNA and miRNA. The mRNA (e.g. VEGF and FGF2) was shown to be involved in the stimulation of angiogenesis as confirmed by the formation of capillaries in vivo after injection of microvesicle-treated HUVEC. When renal tumour cells were injected together with CSC-derived microvesicles into mice, a higher number of metastasis was observed compared to $\mathrm{CD} 105^{-}$cells derived-microvesicle [241].

As already mentioned, CAFs do not just surround the growing tumour passively, but are actively participating in the establishment of a metastasis-promoting communication, influencing at the same time innate and adaptive immune responses. For these reasons, CAFs and their products are now considered potential prognostic biomarkers and candidate targets for novel therapeutic strategies (reviewed in [242]). In CRC stage II and III, $\alpha$ smooth muscle actin (a-SMA)-expressing CAFs were proposed as useful indicators of poor prognosis [243], whereas the combination of calumenin with cadherin 11 expressed by CAFs displayed a significant association with disease-free survival and overall survival [244]. Moreover, in patients with advanced colorectal adenocarcinomas, increased stromal FAP was considered an adverse prognostic marker [245]. A significant correlation was observed between stromal FAP-a and stromal cell-derived factor-1 (SDF-1) mRNA levels, primarily expressed by CAFs, after pre-operative chemo/radiotherapy in rectal cancer patients. FAP-a and SDF-1 gene expression patterns significantly correlated with distant recurrence and poor probability of recurrence-free and overall survival [246]. In another study, multiplex bead immunoassays and an enzyme-linked immunosorbent assays were used to characterize CAFs-signatures from 52 kinds of CAFs in $68 \mathrm{GC}$ patients who were treated with fluoropyrimidine and platinum combination chemotherapy. Serum CAF profiling was able to differentiate GC patients in groups, and more importantly, distinguishing a high 11-CAF signature could identify GC patients with a poor prognosis when treated with standard chemotherapy who need urgent new treatment strategies [247]. Accordingly, Tchou and colleagues observed different gene expression profiles (particularly in pathways associated with cytoskeleton, integrin signalling and metastasis) among early passage primary CAFs derived from three main subtypes $\left(E R^{+}\right.$, triple negative and $\mathrm{Her}^{+}$) of human breast cancer samples, suggesting that CAFs gene expression profile might be a useful marker in breast cancer prognosis [248].

\section{Conclusions and further directions}

More and more evidence is currently supporting the CSCs theory. It is known that CSCs play a crucial role in cancer initiation and primary tumour sustainment. 
These cells can also facilitate the metastasis to distant organs from the primary site. Based on these CSCs properties, it is obvious that they are excellent therapeutic targets, assuming that elimination of the CSC population will block the metastasis and eliminate the possibility of tumour regeneration. Since not only CSCs but also stem cells are able to protect themselves from cellular insult it would be important to probe whether blocking either normal stem cells properties or related pathways can induce CSC sensitivity to selected therapies. Many prevalent treatments were founded based on stem cell pathways: Notch, Hedgehog, or Wnt, among others. Moreover, not only the pathways themselves, and surely not only one single pathway, are important in order to enrich CSCs, but many intra-microenvironmental connections, and relationships between microenvironment and the tumour, play a crucial role in enriching this subpopulation. Also a fundamental step before directly targeting the CSC subpopulation would be characterization of the complex and functional markers. Development of clinical trials related to biomarker strategies would be essential to identify proper endpoints to clinically assess therapies targeting a minority, in most type of cancers, of tumour cells. As already described, the CSC population is heterogeneous. New data obtained with CSC in vitro models provided a broadened knowledge about the nature of these cells. On the top of that, CSCs could give us clues about the identification of stem cell pathways activated during cancer progression, which could guide further therapeutic steps and the precise design of preclinical and clinical trials.

Although further studies are needed to explore the relevance of CSCs in vitro models, it is certainly true that the data based on them have a potential utility for clinical applications. Such prospective therapies also have significant implications for pharmaceutical companies that are seeking to successfully develop a drug in late clinical phases.

\footnotetext{
Abbreviations

5-azaC: azacitidine; ABC: ATP-binding cassette; ALDH: Aldehyde dehydrogenase; AML: Acute myelogenous leukaemia; APL: Acute promyelocytic leukaemia; a-SMA: a-smooth muscle actin; CaExPA: Carcinoma ex-pleomorphic adenoma; CAF: Cancer associated fibroblast; COX2: Cyclooxygenase 2; CSC: Cancer stem cell; CTGF: Connective tissue growth factor; EC: Human embryonal carcinoma; ECM: Extracellular matrix; EGF: Epidermal growth factor; EGFRvIll: Epidermal growth factor receptor vill; EMT: Epithelial-mesenchymal transition; ESC: Embryonic stem cell; ESCC: Esophageal squamous cell cancer; FAP: Fibroblast activation protein; FBS: Foetal bovine serum; GJIC: Gap junctional intercellular communication; GRX: Glutaredoxin; GSH: Glutathione; HA: Hylouronic acid; HDAC: Histone deacetylase; HGF/Met: Hepatocyte growth factor; HH: Hedgehog pathway; HIF: Hypoxia-inducible factor; HSC: Haematopoietic stem cell; I3C: Indole-3carbinol; iCSC: Induced pluripotent cancer stem-like cell; iPC: Induced pluripotent cancer cell; iPCSC: Induced pluripotent cancer stem cell; iPSC: Induced pluripotent stem cell; LSC: Leukaemia initiating stem cell; MIF: Migration inhibitory factor; miRNA: microRNA; MMP: Matrix metalloproteinase; NOD/SCID: Non-obese diabetic severe combined immunodeficient; NSAID: Non-steroid anti-inflammatory drug; NSCLC: Nonsmall cell lung cancer; NSG: Non-obese diabetic scid gamma mice;
}

NT: Nuclear transfer; OSKM: Oct4, Sox2, Klf4, and c-Myc; PA: Pleomorphic adenoma; PanIN: Pancreatic intraepithelial neoplasia; PDAC: Pancreatic ductal adenocarcinoma; PPARg: Peroxisome proliferator activated receptor gamma; ROS: Reactive oxygen species; SAHA: Suberoylanilide hydroxamic acid; SCID: Severe combined immunodeficient; SDF-1: Stromal cell-derived factor1; SHH: Sonic Hedgehog pathway; SP: Side population; TAM: Tumour associated macrophage; TEC: Tumour endothelial cell; TRX: Thioredoxin; TSA: Trichostatin A; UPA: urokinase plasminogen activator; UPAR: urokinase plasminogen activator receptor; VA: Valproic acid; VEGF: Vascular endothelial growth factor; WIF1: Wnt inhibitory factor 1

\section{Acknowledgments}

The authors are indebted to Eoin Sheridan for the critical reading of the manuscript.

\section{Declaration}

This article has been published as part of BMC Cancer Volume 16 Supplement 2, 2016: Proceedings of the 3rd International Genomic Medicine Conference: cancer. The full contents of the supplement are available online at http:// bmccancer.biomedcentral.com/articles/supplements/volume-16-supplement-2.

\section{Funding}

This work was supported by grants from EU FP7 projects (D-BOARD, HEALTH-F2-2012-305815; Anistem, PIAPP-GA-2011-286264; EpiHealth, HEALTH-2012-F2-278418; EpiHealthNet, PITN-GA-2012-317146) and Research Center of Excellence 11476-3/2016/FEKUT. Publication fee was paid by the Centre of Excellence in Genomic Medicine Centre (CEGMR), King Abdulaziz University (KAU), Jeddah, Kingdom of Saudi Arabia.

\section{Availability of data and materials}

Not applicable (review paper).

\section{Authors' contributions}

SSF and KS wrote the manuscript. MSI, AM, JK, and AD edited the final version. All authors read and approved the final version.

\section{Competing interests}

The authors declare that they have no competing interests.

\section{Consent for publication}

Not applicable.

\section{Ethics approval and consent to participate}

Not applicable (review paper).

\section{Author details}

${ }^{1}$ Szent István University, Gödöllö, Hungary. ${ }^{2}$ Biotalentum Ltd., Gödöllö, Hungary. ${ }^{3}$ Beth Israel Deaconess Medical Center, Department of Medicine, Harvard Medical School, Boston, MA, USA. ${ }^{4}$ Center of Excellence in Genomic Medicine Research (CEGMR), King AbdulAziz University, Jeddah, Kingdom of Saudi Arabia. ${ }^{5}$ Department of Veterinary Preclinical Sciences, School of Veterinary Medicine, Faculty of Health and Medical Sciences, University of Surrey, Guildford, Surrey, UK. ${ }^{6}$ Department of Farm Animal Health, Faculty of Veterinary Medicine, Utrecht University, Utrecht, The Netherlands.

Published: 5 October 2016

\section{References}

1. Al-Hajj M, Wicha MS, Benito-Hernandez A, Morrison SJ, Clarke MF. Prospective identification of tumorigenic breast cancer cells. Proc Natl Acad Sci U S A. 2003;100(7):3983-8.

2. Allegra A, Alonci A, Penna G, Innao V, Gerace D, Rotondo F, Musolino C. The cancer stem cell hypothesis: a guide to potential molecular targets. Cancer Invest. 2014;32(9):470-95.

3. Ciurea ME, Georgescu AM, Purcaru SO, Artene SA, Emami GH, Boldeanu MV, Tache DE, Dricu A. Cancer stem cells: biological functions and therapeutically targeting. Int J Mol Sci. 2014;15(5):8169-85.

4. Cho RW, Clarke MF. Recent advances in cancer stem cells. Curr Opin Genet Dev. 2008;18(1):48-53.

5. Hanahan D, Weinberg RA. Hallmarks of cancer: the next generation. Cell. 2011;144(5):646-74. 
6. Lapidot T, Sirard C, Vormoor J, Murdoch B, Hoang T, Caceres-Cortes J, Minden M, Paterson B, Caligiuri MA, Dick JE. A cell initiating human acute myeloid leukaemia after transplantation into SCID mice. Nature. 1994; 367(6464):645-8

7. Bonnet D, Dick JE. Human acute myeloid leukemia is organized as a hierarchy that originates from a primitive hematopoietic cell. Nat Med. 1997;3(7):730-7.

8. Bao S, Wu Q, McLendon RE, Hao Y, Shi Q, Hjelmeland AB, Dewhirst MW, Bigner DD, Rich JN. Glioma stem cells promote radioresistance by preferential activation of the DNA damage response. Nature. 2006; 444(7120):756-60.

9. Tehranchi R, Woll PS, Anderson K, Buza-Vidas N, Mizukami T, Mead AJ, Astrand-Grundstrom I, Strombeck B, Horvat A, Ferry H, et al. Persistent malignant stem cells in del(5q) myelodysplasia in remission. $\mathrm{N}$ Engl J Med. 2010;363(11):1025-37.

10. Visvader JE. Cells of origin in cancer. Nature. 2011;469(7330):314-22.

11. Schatton T, Frank NY, Frank MH. Identification and targeting of cancer stem cells. Bioessays. 2009;31(10):1038-49.

12. Conheim J. Congenitales, quergestreiftes muskelsarkon der nireren. Virchows Arch. 1875;65:64.

13. Patrawala L, Calhoun T, Schneider-Broussard R, Li H, Bhatia B, Tang S, Reilly JG, Chandra D, Zhou J, Claypool K, et al. Highly purified CD44+ prostate cancer cells from xenograft human tumors are enriched in tumorigenic and metastatic progenitor cells. Oncogene. 2006;25(12):1696-708.

14. Wang YC, Yo YT, Lee HY, Liao YP, Chao TK, Su PH, Lai HC. ALDH1-bright epithelial ovarian cancer cells are associated with CD44 expression, drug resistance, and poor clinical outcome. Am J Pathol. 2012;180(3):1159-69.

15. Takaishi S, Okumura T, Tu S, Wang SSW, Shibata W, Vigneshwaran R, Gordon SAK, Shimada Y, Wang TC. Identification of gastric cancer stem cells using the cell surface marker CD44. Stem Cells. 2009;27(5):1006-20.

16. Singh SK, Hawkins C, Clarke ID, Squire JA, Bayani J, Hide T, Henkelman RM, Cusimano MD, Dirks PB. Identification of human brain tumour initiating cells. Nature. 2004;432(7015):396-401.

17. Tirino V, Camerlingo R, Franco R, Malanga D, La Rocca A, Viglietto G, Rocco G, Pirozzi G. The role of CD133 in the identification and characterisation of tumour-initiating cells in non-small-cell lung cancer. Eur J Cardio-Thorac. 2009;36(3):446-53.

18. Lee CJ, Dosch J, Simeone DM. Pancreatic cancer stem cells. J Clin Oncol. 2008;26(17):2806-12

19. Vermeulen L, Todaro M, Mello FD, Sprick MR, Kemper K, Alea MP, Richel DJ, Stassi $\mathrm{G}$, Medema JP. Single-cell cloning of colon cancer stem cells reveals a multilineage differentiation capacity. Proc Natl Acad Sci U S A. 2008;105(36):13427-32.

20. Fujimoto $\mathrm{K}$, Beauchamp RD, Whitehead $\mathrm{RH}$. Identification and isolation of candidate human colonic clonogenic cells based on cell surface integrin expression. Gastroenterology. 2002;123(6):1941-8.

21. Nowell PC. The clonal evolution of tumor cell populations. Science. 1976; 194(4260):23-8.

22. Visvader JE, Lindeman GJ. Cancer stem cells in solid tumours: accumulating evidence and unresolved questions. Nat Rev Cancer. 2008;8(10):755-68.

23. Lobo NA, Shimono Y, Qian D, Clarke MF. The biology of cancer stem cells. Annu Rev Cell Dev Biol. 2007;23:675-99.

24. Reya T, Morrison SJ, Clarke MF, Weissman IL. Stem cells, cancer, and cancer stem cells. Nature. 2001:414(6859):105-11.

25. Feinberg AP, Ohlsson R, Henikoff $\mathrm{S}$. The epigenetic progenitor origin of human cancer. Nat Rev Genet. 2006:7(1):21-33.

26. Weissman IL. Translating stem and progenitor cell biology to the clinic: barriers and opportunities. Science. 2000;287(5457):1442-6.

27. Franco S, Raveh-Amit H, Kobolak J, Alqahtani M, Mobasheri A, Dinnyes A. The crossroads between cancer stem cells and aging. BMC Cancer. 2015;15 Suppl 1:S1.

28. Dayem AA, Choi HY, Kim JH, Cho SG. Role of oxidative stress in stem, cancer, and cancer stem cells. Cancers (Basel). 2010;2(2):859-84.

29. Schepers AG, Snippert HJ, Stange DE, van den Born M, van Es JH, van de Wetering $M$, Clevers $\mathrm{H}$. Lineage tracing reveals Lgr5+ stem cell activity in mouse intestinal adenomas. Science. 2012;337(6095):730-5.

30. Zakaria N, Yusoff NM, Zakaria Z, Lim MN, Baharuddin PJ, Fakiruddin KS, Yahaya B. Human non-small cell lung cancer expresses putative cancer stem cell markers and exhibits the transcriptomic profile of multipotent cells. BMC Cancer. 2015;15:84.

31. Eberle I, Pless B, Braun M, Dingermann T, Marschalek R. Transcriptional properties of human NANOG1 and NANOG2 in acute leukemic cells. Nucleic Acids Res. 2010;38(16):5384-95.
32. Chiou SH, Wang ML, Chou YT, Chen CJ, Hong CF, Hsieh WJ, Chang HT, Chen YS, Lin TW, Hsu HS, et al. Coexpression of Oct4 and Nanog enhances malignancy in lung adenocarcinoma by inducing cancer stem cell-like properties and epithelial-mesenchymal transdifferentiation. Cancer Res. 2010;70(24):10433-44

33. Kong D, Banerjee S, Ahmad A, Li Y, Wang Z, Sethi S, Sarkar FH. Epithelial to mesenchymal transition is mechanistically linked with stem cell signatures in prostate cancer cells. PLoS One. 2010;5(8):e12445.

34. Munoz P, Iliou MS, Esteller M. Epigenetic alterations involved in cancer stem cell reprogramming. Mol Oncol. 2012;6(6):620-36.

35. Krivtsov AV, Twomey D, Feng Z, Stubbs MC, Wang Y, Faber J, Levine JE, Wang J, Hahn WC, Gilliland DG, et al. Transformation from committed progenitor to leukaemia stem cell initiated by MLL-AF9. Nature. 2006; 442(7104):818-22.

36. Nguyen DX, Bos PD, Massague J. Metastasis: from dissemination to organspecific colonization. Nat Rev Cancer. 2009;9(4):274-84

37. Mani SA, Guo W, Liao MJ, Eaton EN, Ayyanan A, Zhou AY, Brooks M, Reinhard F, Zhang CC, Shipitsin M, et al. The epithelial-mesenchymal transition generates cells with properties of stem cells. Cell. 2008;133(4):704-15.

38. Thiery JP, Acloque H, Huang RY, Nieto MA. Epithelial-mesenchymal transitions in development and disease. Cell. 2009;139(5):871-90.

39. Yang ZJ, Ellis T, Markant SL, Read TA, Kessler JD, Bourboulas M, Schuller U, Machold R, Fishell G, Rowitch DH, et al. Medulloblastoma can be initiated by deletion of Patched in lineage-restricted progenitors or stem cells. Cancer Cell. 2008;14(2):135-45.

40. Scheel C, Eaton EN, Li SH, Chaffer CL, Reinhardt F, Kah K, Bell G, Guo W, Rubin J, Richardson AL, et al. Paracrine and autocrine signals induce and maintain mesenchymal and stem cell states in the breast. Cell. 2011;145(6): 926-40.

41. Dylla SJ, Beviglia L, Park IK, Chartier C, Raval J, Ngan L, Pickell K, Aguilar J, Lazetic S, Smith-Berdan S, et al. Colorectal cancer stem cells are enriched in xenogeneic tumors following chemotherapy. PLoS One. 2008;3(6):e2428.

42. Hermann PC, Huber SL, Herrler T, Aicher A, Ellwart JW, Guba M, Bruns CJ, Heeschen C. Distinct populations of cancer stem cells determine tumor growth and metastatic activity in human pancreatic cancer. Cell Stem Cell. 2007;1(3):313-23.

43. Rosen PP. Adenoid cystic carcinoma of the breast. A morphologically heterogeneous neoplasm. Pathol Annu. 1989:24 Pt 2:237-54.

44. Ragaz J, Olivotto IA, Spinelli JJ, Phillips N, Jackson SM, Wilson KS, Knowling MA, Coppin CM, Weir L, Gelmon K, et al. Locoregional radiation therapy in patients with high-risk breast cancer receiving adjuvant chemotherapy: 20year results of the British Columbia randomized trial. J Natl Cancer Inst. 2005:97(2):116-26.

45. Patel SA, Ramkissoon SH, Bryan M, Pliner LF, Dontu G, Patel PS, Amiri S, Pine SR, Rameshwar P. Delineation of breast cancer cell hierarchy identifies the subset responsible for dormancy. Sci Rep. 2012;2:906.

46. Valent $\mathrm{P}$, Bonnet D, De Maria R, Lapidot T, Copland M, Melo JV, Chomienne C, Ishikawa F, Schuringa JJ, Stassi G, et al. Cancer stem cell definitions and terminology: the devil is in the details. Nat Rev Cancer. 2012;12(11):767-75.

47. Quintana E, Shackleton M, Sabel MS, Fullen DR, Johnson TM, Morrison SJ. Efficient tumour formation by single human melanoma cells. Nature. 2008; 456(7222):593-8.

48. Ishizawa K, Rasheed ZA, Karisch R, Wang Q, Kowalski J, Susky E, Pereira K, Karamboulas C, Moghal N, Rajeshkumar NV, et al. Tumor-initiating cells are rare in many human tumors. Cell Stem Cell. 2010;7(3):279-82

49. Kuperwasser C, Chavarria T, Wu M, Magrane G, Gray JW, Carey L, Richardson A, Weinberg RA. Reconstruction of functionally normal and malignant human breast tissues in mice. Proc Natl Acad Sci U S A. 2004;101(14):4966-71.

50. Morton JJ, Bird G, Keysar SB, Astling DP, Lyons TR, Anderson RT, Glogowska MJ, Estes P, Eagles JR, Le PN, et al. XactMice: humanizing mouse bone marrow enables microenvironment reconstitution in a patient-derived xenograft model of head and neck cancer. Oncogene. 2015.

51. Langan RC, Mullinax JE, Raiji MT, Upham T, Summers T, Stojadinovic A, Avital I. Colorectal cancer biomarkers and the potential role of cancer stem cells. J Cancer. 2013;4(3):241-50.

52. Utikal J, Maherali N, Kulalert W, Hochedlinger K. Sox2 is dispensable for the reprogramming of melanocytes and melanoma cells into induced pluripotent stem cells. J Cell Sci. 2009;122(19):3502-10.

53. Lin SL, Chang DC, Chang-Lin S, Lin CH, Wu DTS, Chen DT, Ying SY. Mir-302 reprograms human skin cancer cells into a pluripotent ES-cell-like state. RNA. 2008;14(10):2115-24. 
54. Mahalingam D, Kong CM, Lai J, Tay LL, Yang H, Wang XY. Reversal of aberrant cancer methylome and transcriptome upon direct reprogramming of lung cancer cells. Sci Rep-Uk. 2012;2:1-10.

55. Mathieu J, Zhang Z, Zhou WY, Wang AJ, Heddleston JM, Pinna CMA, Hubaud A, Stadler B, Choi M, Bar M, et al. HIF induces human embryonic stem cell markers in cancer cells. Cancer Res. 2011;71(13):4640-52.

56. Saito A, Ochiai H, Okada S, Miyata N, Azuma T. Suppression of Lefty expression in induced pluripotent cancer cells. Faseb J. 2013;27(6):2165-74.

57. Miyoshi N, Ishii H, Nagai K, Hoshino H, Mimori K, Tanaka F, Nagano H, Sekimoto M, Doki Y, Mori M. Defined factors induce reprogramming of gastrointestinal cancer cells. Proc Natl Acad Sci U S A. 2010;107(1):40-5.

58. Hoshino $H$, Nagano $H$, Haraguchi N, Nishikawa S, Tomokuni A, Kano $Y$, Fukusumi T, Saito T, Ozaki M, Sakai D, et al. Hypoxia and TP53 deficiency for induced pluripotent stem cell-like properties in gastrointestinal cancer. Int J Oncol. 2012:40(5):1423-30.

59. Liu YH, Li Y, Liu XH, Sui HM, Liu YX, Xiao ZQ, Zheng P, Chen L, Yao S, Xing $C$, et al. A signature for induced pluripotent stem cell-associated genes in colorectal cancer. Med Oncol. 2013;30(1):1-11.

60. Nagai K, Ishii H, Miyoshi N, Hoshino H, Saito T, Sato T, Tomimaru Y, Kobayashi S, Nagano H, Sekimoto M, et al. Long-term culture following ESlike gene-induced reprogramming elicits an aggressive phenotype in mutated cholangiocellular carcinoma cells. Biochem Bioph Res Co. 2010; 395(2):258-63

61. Zhang X, Cruz FD, Terry M, Remotti F, Matushansky I. Terminal differentiation and loss of tumorigenicity of human cancers via pluripotency-based reprogramming. Oncogene. 2013;32(18):2249-60. 2260 e2241-2221.

62. Leis O, Eguiara A, Lopez-Arribillaga E, Alberdi MJ, Hernandez-Garcia S, Elorriaga K, Pandiella A, Rezola R, Martin AG. Sox2 expression in breast tumours and activation in breast cancer stem cells. Oncogene. 2012;31(11):1354-65.

63. Corominas-Faja B, Cufi S, Oliveras-Ferraros C, Cuyas E, Lopez-Bonet E, Lupu $\mathrm{R}$, Alarcon $\mathrm{T}$, Vellon $\mathrm{L}$, Iglesias JM, Leis $\mathrm{O}$, et al. Nuclear reprogramming of luminal-like breast cancer cells generates Sox2-overexpressing cancer stemlike cellular states harboring transcriptional activation of the mTOR pathway. Cell Cycle. 2013;12(18):3109-24.

64. Vazquez-Martin A, Cufi S, Lopez-Bonet E, Corominas-Faja B, Cuyas E, Vellon L, Iglesias JM, Leis O, Martin AG, Menendez JA. Reprogramming of non-genomic estrogen signaling by the stemness factor SOX2 enhances the tumor-initiating capacity of breast cancer cells. Cell Cycle. 2013;12(22):3471-7.

65. Vencio EF, Nelson AM, Cavanaugh C, Ware CB, Milller DG, Garcia JC, Vencio RZ, Loprieno MA, Liu AY. Reprogramming of prostate cancer-associated stromal cells to embryonic stem-like. Prostate. 2012;72(13):1453-63.

66. Carette JE, Pruszak J, Varadarajan M, Blomen VA, Gokhale S, Camargo FD, Wernig M, Jaenisch R, Brummelkamp TR. Generation of iPSCs from cultured human malignant cells. Blood. 2010;115(20):4039-42.

67. Kumano K, Arai S, Hosoi M, Taoka K, Takayama N, Otsu M, Nagae G, Ueda K, Nakazaki K, Kamikubo Y, et al. Generation of induced pluripotent stem cells from primary chronic myelogenous leukemia patient samples. Blood. 2012; 119(26):6234-42

68. Hu KJ, Yu JY, Suknuntha K, Tian SL, Montgomery K, Choi KD, Stewart R, Thomson JA, Slukvin II. Efficient generation of transgene-free induced pluripotent stem cells from normal and neoplastic bone marrow and cord blood mononuclear cells. Blood. 2011:117(14):E109-19.

69. Kim J, Hoffman JP, Alpaugh RK, Rhim AD, Reichert M, Stanger BZ, Furth EE, Sepulveda AR, Yuan CX, Won KJ, et al. An iPSC line from human pancreatic ductal adenocarcinoma undergoes early to invasive stages of pancreatic cancer progression. Cell Rep. 2013;3(6):2088-99.

70. Mather JP. In vitro models. Stem Cells. 2012;30(2):95-9

71. Yenigun VB, Ozpolat B, Kose GT. Response of CD44+/CD24-/low breast cancer stem/progenitor cells to tamoxifen and doxorubicininduced autophagy. Int J Mol Med. 2013;31(6):1477-83.

72. Kondo T, Setoguchi T, Taga T. Persistence of a small subpopulation of cancer stemlike cells in the C6 glioma cell line. Proc Natl Acad Sci U S A. 2004;101(3):781-6.

73. Boesch M, Zeimet AG, Reimer D, Schmidt S, Gastl G, Parson W, Spoeck F, Hatina J, Wolf D, Sopper S. The side population of ovarian cancer cells defines a heterogeneous compartment exhibiting stem cell characteristics. Oncotarget. 2014;5(16):7027-39.

74. Niess H, Camaj P, Renner A, Ischenko I, Zhao Y, Krebs S, Mysliwietz J, Jackel C, Nelson PJ, Blum H, et al. Side population cells of pancreatic cancer show characteristics of cancer stem cells responsible for resistance and metastasis. Target Oncol. 2014.
75. Patrawala L, Calhoun T, Schneider-Broussard R, Zhou J, Claypool K, Tang DG. Side population is enriched in tumorigenic, stem-like cancer cells, whereas ABCG2+ and ABCG2- cancer cells are similarly tumorigenic. Cancer Res. 2005:65(14):6207-19.

76. Huang D, Gao Q, Guo L, Zhang C, Jiang W, Li H, Wang J, Han X, Shi Y, Lu $\mathrm{SH}$. Isolation and identification of cancer stem-like cells in esophageal carcinoma cell lines. Stem Cells Dev. 2009;18(3):465-73.

77. Hadnagy A, Gaboury L, Beaulieu R, Balicki D. SP analysis may be used to identify cancer stem cell populations. Exp Cell Res. 2006;312(19):3701-10.

78. Wu C, Alman BA. Side population cells in human cancers. Cancer Lett. 2008; 268(1):1-9.

79. Harrison H, Farnie G, Howell SJ, Rock RE, Stylianou S, Brennan KR, Bundred $\mathrm{NJ}$, Clarke RB. Regulation of breast cancer stem cell activity by signalling through the Notch4 receptor. Cancer Res. 2010;70(2):709-18.

80. Charafe-Jauffret $E$, Ginestier C, lovino F, Wicinski J, Cervera N, Finetti $P$, Hur $\mathrm{MH}$, Diebel ME, Monville F, Dutcher J, et al. Breast cancer cell lines contain functional cancer stem cells with metastatic capacity and a distinct molecular signature. Cancer Res. 2009;69(4):1302-13.

81. Nagata S, Hirano K, Kanemori M, Sun L-T, Tada T. Self-renewal and pluripotency acquired through somatic reprogramming to human cancer stem cells. PLoS One. 2012;7(11):e48699.

82. Scaffidi P, Misteli T. In vitro generation of human cells with cancer stem cell properties. Nat Cell Biol. 2011;13(9):1051-61.

83. Chen L, Kasai T, Li Y, Sugii Y, Jin G, Okada M, Vaidyanath A, Mizutani A, Satoh A, Kudoh T, et al. A model of cancer stem cells derived from mouse induced pluripotent stem cells. PLoS One. 2012;7(4):e33544.

84. Kim J, Zaret KS. Reprogramming of human cancer cells to pluripotency for models of cancer progression. EMBO J. 2015;34(6):739-47.

85. Mintz B, Illmensee K. Normal genetically mosaic mice produced from malignant teratocarcinoma cells. Proc Natl Acad Sci U S A. 1975;72(9):3585-9.

86. Lin TP. Microinjection of mouse eggs. Science. 1966;151(3708):333-7.

87. Allegrucci C, Rushton MD, Dixon JE, Sottile V, Shah M, Kumari R, Watson S, Alberio $R$, Johnson AD. Epigenetic reprogramming of breast cancer cells with oocyte extracts. Mol Cancer. 2011;10(1):7.

88. Hochedlinger K, Blelloch R, Brennan C, Yamada Y, Kim M, Chin L, Jaenisch R. Reprogramming of a melanoma genome by nuclear transplantation. Genes Dev. 2004;18(15):1875-85.

89. Blelloch RH, Hochedlinger K, Yamada Y, Brennan C, Kim M, Mintz B, Chin L, Jaenisch R. Nuclear cloning of embryonal carcinoma cells. Proc Natl Acad Sci U S A. 2004;101(39):13985-90.

90. Takahashi K, Yamanaka S. Induction of pluripotent stem cells from mouse embryonic and adult fibroblast cultures by defined factors. Cell. 2006;126(4):663-76.

91. Merkl C, Saalfrank A, Riesen N, Kuhn R, Pertek A, Eser S, Hardt MS, Kind A, Saur D, Wurst W, et al. Efficient generation of rat induced pluripotent stem cells using a non-viral inducible vector. PLoS One. 2013;8(1):1-13.

92. Honda A, Hirose M, Hatori M, Matoba S, Miyoshi H, Inoue K, Ogura A. Generation of induced pluripotent stem cells in rabbits: potential experimental models for human regenerative medicine. J Biol Chem. 2010;285(41):31362-9.

93. Ezashi T, Telugu BP, Alexenko AP, Sachdev S, Sinha S, Roberts RM Derivation of induced pluripotent stem cells from pig somatic cells. Proc Natl Acad Sci U S A. 2009;106(27):10993-8.

94. Zhu FF, Zhang PB, Zhang DH, Sui X, Yin M, Xiang TT, Shi Y, Ding MX, Deng $H$. Generation of pancreatic insulin-producing cells from rhesus monkey induced pluripotent stem cells. Diabetologia. 2011:54(9):2325-36.

95. Yu JY, Vodyanik MA, Smuga-Otto K, Antosiewicz-Bourget J, Frane JL, Tian S, Nie J, Jonsdottir GA, Ruotti V, Stewart R, et al. Induced pluripotent stem cell lines derived from human somatic cells. Science. 2007;318(5858):1917-20.

96. Park $\mathrm{H}$, Zhao R, West JA, Yabuuchi A, Huo H, Ince TA, Lerou PH, Lensch MW, Daley GQ. Reprogramming of human somatic cells to pluripotency with defined factors. Nature. 2008:451(7175):141-6.

97. Takahashi K, Tanabe K, Ohnuki M, Narita M, Ichisaka T, Tomoda K, Yamanaka S. Induction of pluripotent stem cells from adult human fibroblasts by defined factors. Cell. 2007:131(5):861-72.

98. Oshima N, Yamada Y, Nagayama S, Kawada K, Hasegawa S, Okabe H, Sakai $Y$, Aoi T. Induction of cancer stem cell properties in colon cancer cells by defined factors. PLoS One. 2014;9(7):e101735.

99. Koga C, Kobayashi S, Nagano H, Tomimaru Y, Hama N, Wada H, Kawamoto $\mathrm{K}$, Eguchi $\mathrm{H}$, Konno M, Ishii $\mathrm{H}$ et al: Reprogramming using microRNA-302 improves drug sensitivity in hepatocellular carcinoma cells. Annals of Surgical Oncology. 2014:S591-\$600 
100. Debeb BG, Lacerda L, Xu W, Larson R, Solley T, Atkinson R, Sulman EP, Ueno NT, Krishnamurthy S, Reuben JM, et al. Histone deacetylase inhibitors stimulate dedifferentiation of human breast cancer cells through WNT/betacatenin signaling. Stem Cells. 2012;30(11):2366-77.

101. Semi K, Matsuda Y, Ohnishi K, Yamada Y. Cellular reprogramming and cancer development. Int J Cancer. 2013;132(6):1240-8.

102. Stricker SH, Pollard SM. Reprogramming cancer cells to pluripotency An experimental tool for exploring cancer epigenetics. Epigenetics. 2014;9(6): 798-802.

103. Li H, Collado M, Villasante A, Strati K, Ortega S, Canamero M, Blasco MA, Serrano M. The Ink4/Arf locus is a barrier for iPS cell reprogramming. Nature. 2009;460(7259):1136-U1101.

104. Han JN, Sachdev PS, Sidhu KS. A Combined Epigenetic and Non-Genetic Approach for Reprogramming Human Somatic Cells. PLoS One. 2010;5(8): 11-13.

105. Ma T, Xie M, Laurent T, Ding S. Progress in the reprogramming of somatic cells. Circ Res. 2013;112(3):562-74.

106. Yamanaka $\mathrm{S}$. Elite and stochastic models for induced pluripotent stem cell generation. Nature. 2009;460(7251):49-52.

107. Lai J, Kong CM, Mahalingam D, Xie X, Wang X. Elite model for the generation of induced pluripotent cancer cells (iPCS). PLoS One. 2013;8(2):e56702.

108. Kim K, Doi A, Wen B, Ng K, Zhao R, Cahan P, Kim J, Aryee MJ, Ji H, Ehrlich LI, et al. Epigenetic memory in induced pluripotent stem cells. Nature. 2010; 467(7313):285-90.

109. Stricker SH, Feber A, Engstrom PG, Caren H, Kurian KM, Takashima Y, Watts C, Way $M$, Dirks $P$, Bertone $P$, et al. Widespread resetting of DNA methylation in glioblastoma-initiating cells suppresses malignant cellular behavior in a lineage-dependent manner. Gene Dev. 2013;27(6):654-69.

110. Moore JB, Loeb DM, Hong KU, Sorensen PH, Triche TJ, Lee DW, Barbato MI, Arceci RJ. Epigenetic reprogramming and re-differentiation of a Ewing sarcoma cell line. Front Cell Dev Biol. 2015;3:15.

111. Pitha-Rowe I, Petty WJ, Kitareewan S, Dmitrovsky E. Retinoid target genes in acute promyelocytic leukemia. Leukemia. 2003;17(9):1723-30.

112. Charytonowicz E, Terry M, Coakley K, Telis L, Remotti F, Cordon-Cardo C, Taub RN, Matushansky I. PPARgamma agonists enhance ET-743-induced adipogenic differentiation in a transgenic mouse model of myxoid round cell liposarcoma. J Clin Invest. 2012;122(3):886-98.

113. Richon VM, Emiliani S, Verdin E, Webb Y, Breslow R, Rifkind RA, Marks PA. A class of hybrid polar inducers of transformed cell differentiation inhibits histone deacetylases. Proc Natl Acad Sci U S A. 1998;95(6):3003-7.

114. George AA, Franklin J, Kerkof K, Shah AJ, Price M, Tsark E, Bockstoce D, Yao D, Hart N, Carcich S, et al. Detection of leukemic cells in the CD34(+)CD38(-) bone marrow progenitor population in children with acute lymphoblastic leukemia. Blood. 2001;97(12):3925-30.

115. Elkord AJE. Significance of CD44 and CD24 as cancer stem cell markers: an enduring ambiguity. Clin Dev Immunol. 2012;2012:11.

116. Quan Y, Yan Y, Wang X, Fu Q, Wang W, Wu J, Yang G, Ren J, Wang Y. Impact of cell dissociation on identification of breast cancer stem cells. Cancer Biomark. 2012;12(3):125-33.

117. Armstrong L, Stojkovic M, Dimmick I, Ahmad S, Stojkovic P, Hole N, Lako M. Phenotypic characterization of murine primitive hematopoietic progenitor cells isolated on basis of aldehyde dehydrogenase activity. Stem Cells. 2004; 22(7):1142-51.

118. Cheung AM, Wan TS, Leung JC, Chan LY, Huang H, Kwong YL, Liang R, Leung AY. Aldehyde dehydrogenase activity in leukemic blasts defines a subgroup of acute myeloid leukemia with adverse prognosis and superior NOD/SCID engrafting potential. Leukemia. 2007;21(7):1423-30.

119. Ginestier C, Hur MH, Charafe-Jauffret E, Monville F, Dutcher J, Brown M, Jacquemier J, Viens $P$, Kleer CG, Liu S, et al. ALDH1 is a marker of normal and malignant human mammary stem cells and a predictor of poor clinical outcome. Cell Stem Cell. 2007;1(5):555-67.

120. Paoli P, Giannoni E, Chiarugi P. Anoikis molecular pathways and its role in cancer progression. Biochim Biophys Acta. 2013;1833(12):3481-98.

121. Lu S, Labhasetwar V. Drug resistant breast cancer cell line displays cancer stem cell phenotype and responds sensitively to epigenetic drug SAHA. Drug Deliv Transl Res. 2013;3(2):183-94.

122. Tang QL, Liang Y, Xie XB, Yin JQ, Zou CY, Zhao ZQ, Shen JN, Wang J. Enrichment of osteosarcoma stem cells by chemotherapy. Chin J Cancer. 2011;30(6):426-32.

123. Li HZ, Yi TB, Wu ZY. Suspension culture combined with chemotherapeutic agents for sorting of breast cancer stem cells. BMC Cancer. 2008:8:135.
124. Weiswald LB, Bellet D, Dangles-Marie V. Spherical cancer models in tumor biology. Neoplasia. 2015;17(1):1-15.

125. Cao L, Zhou Y, Zhai B, Liao J, Xu W, Zhang R, Li J, Zhang Y, Chen L, Qian H, et al. Sphere-forming cell subpopulations with cancer stem cell properties in human hepatoma cell lines. BMC Gastroenterol. 2011;11:71.

126. Wang YJ, Bailey JM, Rovira M, Leach SD. Sphere-forming assays for assessment of benign and malignant pancreatic stem cells. Methods Mol Biol. 2013;980:281-90.

127. Zhang G, Ma L, Xie YK, Miao XB, Jin C. Esophageal cancer tumorspheres involve cancer stem-like populations with elevated aldehyde dehydrogenase enzymatic activity. Mol Med Rep. 2012;6(3):519-24.

128. Pollard SM, Yoshikawa K, Clarke ID, Danovi D, Stricker S, Russell R, Bayani J, Head R, Lee M, Bernstein M, et al. Glioma stem cell lines expanded in adherent culture have tumor-specific phenotypes and are suitable for chemical and genetic screens. Cell Stem Cell. 2009;4(6):568-80.

129. Pastrana E, Silva-Vargas V, Doetsch F. Eyes wide open: a critical review of sphere-formation as an assay for stem cells. Cell Stem Cell. 2011;8(5):486-98.

130. Louie E, Nik S, Chen JS, Schmidt M, Song B, Pacson C, Chen XF, Park S, Ju J, Chen El. Identification of a stem-like cell population by exposing metastatic breast cancer cell lines to repetitive cycles of hypoxia and reoxygenation. Breast Cancer Res. 2010;12(6):R94.

131. Kelly PN, Dakic A, Adams JM, Nutt SL, Strasser A. Tumor growth need not be driven by rare cancer stem cells. Science. 2007;317(5836):337.

132. Somervaille TC, Cleary ML. Identification and characterization of leukemia stem cells in murine MLL-AF9 acute myeloid leukemia. Cancer Cell. 2006;10(4):257-68.

133. Li X, Lewis MT, Huang J, Gutierrez C, Osborne CK, Wu MF, Hilsenbeck SG, Pavlick A, Zhang X, Chamness GC, et al. Intrinsic resistance of tumorigenic breast cancer cells to chemotherapy. J Natl Cancer Inst. 2008;100(9):672-9.

134. Sachlos E, Risueño Ruth M, Laronde S, Shapovalova Z, Lee J-H, Russell J, Malig M, McNicol Jamie D, Fiebig-Comyn A, Graham M, et al. Identification of drugs including a dopamine receptor antagonist that selectively target cancer stem cells. Cell. 2012;149(6):1284-97.

135. Boston Biomedical. Boston Biomedical Data at ASCO 2015 Highlights Potential of Novel Investigational Cancer Stem Cell Pathway Inhibitors BBI608 and BBI503 in Multiple Cancer Types. http://bostonbiomedical.com/ boston-biomedical-data-at-asco-2015-highlights-potential-of-novelinvestigational-cancer-stem-cell-pathway-inhibitors-bbi608-and-bbi503-inmultiple-cancer-types/ (2015). Accessed 18 Feb 2016.

136. Lander AD, Kimble J, Clevers H, Fuchs E, Montarras D, Buckingham M, Calof AL, Trumpp A, Oskarsson T. What does the concept of the stem cell niche really mean today? BMC Biol. 2012;10:19.

137. Hofmeister V, Schrama D, Becker JC. Anti-cancer therapies targeting the tumor stroma. Cancer Immunol Immunother. 2008;57(1):1-17.

138. Reisfeld RA. The tumor microenvironment: a target for combination therapy of breast cancer. Crit Rev Oncog. 2013;18(1-2):115-33.

139. Scott AM, Wiseman G, Welt S, Adjei A, Lee FT, Hopkins W, Divgi CR, Hanson LH, Mitchell P, Gansen DN, et al. A Phase I dose-escalation study of sibrotuzumab in patients with advanced or metastatic fibroblast activation protein-positive cancer. Clin Cancer Res. 2003;9(5):1639-47.

140. Mann J, Oakley F, Akiboye F, Elsharkawy A, Thorne AW, Mann DA. Regulation of myofibroblast transdifferentiation by DNA methylation and MeCP2: implications for wound healing and fibrogenesis. Cell Death Differ. 2007;14(2):275-85.

141. Hemers E, Duval C, McCaig C, Handley M, Dockray GJ, Varro A. Insulin-like growth factor binding protein-5 is a target of matrix metalloproteinase-7: implications for epithelial-mesenchymal signaling. Cancer Res. 2005;65(16):7363-9.

142. Kim KJ, Wang L, Su YC, Gillespie GY, Salhotra A, Lal B, Laterra J. Systemic antihepatocyte growth factor monoclonal antibody therapy induces the regression of intracranial glioma xenografts. Clin Cancer Res. 2006;12(4):1292-8.

143. Wen J, Matsumoto K, Taniura N, Tomioka D, Nakamura T. Hepatic gene expression of NK4, an HGF-antagonist/angiogenesis inhibitor, suppresses liver metastasis and invasive growth of colon cancer in mice. Cancer Gene Ther. 2004;11(6):419-30.

144. Qu CF, Song EY, Li Y, Rizvi SM, Raja C, Smith R, Morgenstern A, Apostolidis C, Allen BJ. Pre-clinical study of 213Bi labeled PAI2 for the control of micrometastatic pancreatic cancer. Clin Exp Metastasis. 2005;22(7):575-86.

145. Pulukuri SM, Gondi CS, Lakka SS, Jutla A, Estes N, Gujrati M, Rao JS. RNA interference-directed knockdown of urokinase plasminogen activator and urokinase plasminogen activator receptor inhibits prostate cancer cell invasion, survival, and tumorigenicity in vivo. J Biol Chem. 2005;280(43):36529-40.

146. De Wever O, Nguyen QD, Van Hoorde L, Bracke M, Bruyneel E, Gespach C, Mareel M. Tenascin-C and SF/HGF produced by myofibroblasts in vitro 
provide convergent pro-invasive signals to human colon cancer cells through RhoA and Rac. Faseb J. 2004;18(9):1016-8.

147. Reardon DA, Rich JN, Friedman HS, Bigner DD. Recent advances in the treatment of malignant astrocytoma. J Clin Oncol. 2006;24(8):1253-65.

148. Aikawa T, Gunn J, Spong SM, Klaus SJ, Korc M. Connective tissue growth factor-specific antibody attenuates tumor growth, metastasis, and angiogenesis in an orthotopic mouse model of pancreatic cancer. Mol Cancer Ther. 2006;5(5):1108-16.

149. Gilbertson RJ, Rich JN. Making a tumour's bed: glioblastoma stem cells and the vascular niche. Nat Rev Cancer. 2007:7(10):733-6.

150. Calabrese C, Poppleton H, Kocak M, Hogg TL, Fuller C, Hamner B, Oh EY, Gaber MW, Finklestein D, Allen M, et al. A perivascular niche for brain tumor stem cells. Cancer Cell. 2007;11(1):69-82.

151. Friedman HS, Prados MD, Wen PY, Mikkelsen T, Schiff D, Abrey LE, Yung WK, Paleologos N, Nicholas MK, Jensen R, et al. Bevacizumab alone and in combination with irinotecan in recurrent glioblastoma. J Clin Oncol. 2009; 27(28):4733-40.

152. Batchelor TT, Sorensen AG, di Tomaso E, Zhang WT, Duda DG, Cohen KS, Kozak KR, Cahill DP, Chen PJ, Zhu M, et al. AZD2171, a pan-VEGF receptor tyrosine kinase inhibitor, normalizes tumor vasculature and alleviates edema in glioblastoma patients. Cancer Cell. 2007;11(1):83-95.

153. Konopleva M, Zhao S, Hu W, Jiang S, Snell V, Weidner D, Jackson CE, Zhang $X$, Champlin R, Estey E, et al. The anti-apoptotic genes $B C l-X(L)$ and $B C l-2$ are over-expressed and contribute to chemoresistance of non-proliferating leukaemic CD34+ cells. Br J Haematol. 2002;118(2):521-34.

154. Kang MH, Reynolds CP. BCl-2 inhibitors: targeting mitochondrial apoptotic pathways in cancer therapy. Clin Cancer Res. 2009;15(4):1126-32.

155. Dottori M, Down M, Huttmann A, Fitzpatrick DR, Boyd AW. Cloning and characterization of EphA3 (Hek) gene promoter: DNA methylation regulates expression in hematopoietic tumor cells. Blood. 1999;94(7):2477-86.

156. Provenzano PP, Cuevas C, Chang AE, Goel VK, Von Hoff DD, Hingorani SR. Enzymatic targeting of the stroma ablates physical barriers to treatment of pancreatic ductal adenocarcinoma. Cancer Cell. 2012;21(3):418-29.

157. Heddleston JM, Li Z, McLendon RE, Hjelmeland AB, Rich JN. The hypoxic microenvironment maintains glioblastoma stem cells and promotes reprogramming towards a cancer stem cell phenotype. Cell Cycle. 2009; 8(20):3274-84.

158. Semenza GL. Defining the role of hypoxia-inducible factor 1 in cancer biology and therapeutics. Oncogene. 2010;29(5):625-34.

159. Gurney A, Axelrod F, Bond CJ, Cain J, Chartier C, Donigan L, Fischer M, Chaudhari A, Ji M, Kapoun AM, et al. Wnt pathway inhibition via the targeting of Frizzled receptors results in decreased growth and tumorigenicity of human tumors. Proc Natl Acad Sci U S A. 2012;109(29):11717-22.

160. Hoey T, Yen WC, Axelrod F, Basi J, Donigian L, Dylla S, Fitch-Bruhns M, Lazetic S, Park IK, Sato A, et al. DLL4 blockade inhibits tumor growth and reduces tumor-initiating cell frequency. Cell Stem Cell. 2009;5(2):168-77.

161. Reya T, Clevers H. Wnt signalling in stem cells and cancer. Nature. 2005; 434(7035):843-50.

162. Chien AJ, Conrad WH, Moon RT. A Wnt survival guide: from flies to human disease. J Invest Dermatol. 2009;129(7):1614-27.

163. Boon EM, Keller JJ, Wormhoudt TA, Giardiello FM, Offerhaus GJ, van der Neut $R$, Pals ST. Sulindac targets nuclear beta-catenin accumulation and Wnt signalling in adenomas of patients with familial adenomatous polyposis and in human colorectal cancer cell lines. Br J Cancer. 2004;90(1):224-9.

164. Hawcroft G, D'Amico M, Albanese C, Markham AF, Pestell RG, Hull MA Indomethacin induces differential expression of beta-catenin, gammacatenin and T-cell factor target genes in human colorectal cancer cells. Carcinogenesis. 2002;23(1):107-14.

165. Tuynman JB, Vermeulen L, Boon EM, Kemper K, Zwinderman AH, Peppelenbosch MP, Richel DJ. Cyclooxygenase-2 inhibition inhibits c-Met kinase activity and Wnt activity in colon cancer. Cancer Res. 2008:68(4):1213-20.

166. Ramachandran I, Ganapathy V, Gillies E, Fonseca I, Sureban SM, Houchen CW, Reis A, Queimado L. Wnt inhibitory factor 1 suppresses cancer stemness and induces cellular senescence. Cell Death Dis. 2014;5:e1246.

167. Clement V, Sanchez P, de Tribolet N, Radovanovic I, Ruiz i Altaba A. HEDGEHOG-GLI1 signaling regulates human glioma growth, cancer stem cell self-renewal, and tumorigenicity. Curr Biol. 2007;17(2):165-72.

168. Kalderon D. Transducing the hedgehog signal. Cell. 2000;103(3):371-4.

169. Cooper MK, Porter JA, Young KE, Beachy PA. Teratogen-mediated inhibition of target tissue response to Shh signaling. Science. 1998;280(5369):1603-7.
170. Incardona JP, Gaffield W, Kapur RP, Roelink H. The teratogenic Veratrum alkaloid cyclopamine inhibits sonic hedgehog signal transduction. Development. 1998;125(18):3553-62.

171. Scales SJ, de Sauvage FJ. Mechanisms of Hedgehog pathway activation in cancer and implications for therapy. Trends Pharmacol Sci. 2009;30(6):303-12.

172. Peacock CD, Wang Q, Gesell GS, Corcoran-Schwartz IM, Jones E, Kim J, Devereux WL, Rhodes JT, Huff CA, Beachy PA, et al. Hedgehog signaling maintains a tumor stem cell compartment in multiple myeloma. Proc Natl Acad Sci U S A. 2007;104(10):4048-53.

173. Lauth M, Bergstrom A, Shimokawa T, Toftgard R. Inhibition of GLI-mediated transcription and tumor cell growth by small-molecule antagonists. Proc Natl Acad Sci U S A. 2007;104(20):8455-60.

174. Beauchamp EM, Ringer L, Bulut G, Sajwan KP, Hall MD, Lee YC, Peaceman D, Ozdemirli M, Rodriguez O, Macdonald TJ, et al. Arsenic trioxide inhibits human cancer cell growth and tumor development in mice by blocking Hedgehog/GLI pathway. J Clin Invest. 2011;121(1):148-60.

175. Yilmaz OH, Valdez R, Theisen BK, Guo W, Ferguson DO, Wu H, Morrison SJ. Pten dependence distinguishes haematopoietic stem cells from leukaemiainitiating cells. Nature. 2006;441(7092):475-82.

176. Zhou J, Wulfkuhle J, Zhang H, Gu P, Yang Y, Deng J, Margolick JB, Liotta LA, Petricoin 3rd E, Zhang Y. Activation of the PTEN/mTOR/STAT3 pathway in breast cancer stem-like cells is required for viability and maintenance. Proc Natl Acad Sci U S A. 2007;104(41):16158-63.

177. Hess G, Herbrecht R, Romaguera J, Verhoef G, Crump M, Gisselbrecht C, Laurell A, Offner F, Strahs A, Berkenblit A, et al. Phase III study to evaluate temsirolimus compared with investigator's choice therapy for the treatment of relapsed or refractory mantle cell lymphoma. J Clin Oncol. 2009;27(23): 3822-9.

178. Yao JC, Shah MH, Ito T, Bohas CL, Wolin EM, Van Cutsem E, Hobday TJ, Okusaka T, Capdevila J, de Vries EG, et al. Everolimus for advanced pancreatic neuroendocrine tumors. N Engl J Med. 2011;364(6):514-23.

179. Yu K, Toral-Barza L, Shi C, Zhang WG, Lucas J, Shor B, Kim J, Verheijen J, Curran K, Malwitz DJ, et al. Biochemical, cellular, and in vivo activity of novel ATP-competitive and selective inhibitors of the mammalian target of rapamycin. Cancer Res. 2009;69(15):6232-40.

180. Mueller MT, Hermann PC, Witthauer J, Rubio-Viqueira B, Leicht SF, Huber S, Ellwart JW, Mustafa M, Bartenstein P, D'Haese JG, et al. Combined targeted treatment to eliminate tumorigenic cancer stem cells in human pancreatic cancer. Gastroenterology. 2009;137(3):1102-13.

181. Dowling RJ, Zakikhani M, Fantus IG, Pollak M, Sonenberg N. Metformin inhibits mammalian target of rapamycin-dependent translation initiation in breast cancer cells. Cancer Res. 2007;67(22):10804-12.

182. Bao B, Wang Z, Ali S, Ahmad A, Azmi AS, Sarkar SH, Banerjee S, Kong D, Li Y, Thakur $S$, et al. Metformin inhibits cell proliferation, migration and invasion by attenuating CSC function mediated by deregulating miRNAs in pancreatic cancer cells. Cancer Prev Res (Phila). 2012;5(3):355-64.

183. Hirsch HA, Iliopoulos D, Tsichlis PN, Struhl K. Metformin selectively targets cancer stem cells, and acts together with chemotherapy to block tumor growth and prolong remission. Cancer Res. 2009;69(19):7507-11.

184. Shank JJ, Yang K, Ghannam J, Cabrera L, Johnston CJ, Reynolds RK, Buckanovich RJ. Metformin targets ovarian cancer stem cells in vitro and in vivo. Gynecol Oncol. 2012;127(2):390-7.

185. Dontu G, Jackson KW, McNicholas E, Kawamura MJ, Abdallah WM, Wicha MS. Role of Notch signaling in cell-fate determination of human mammary stem/progenitor cells. Breast Cancer Res. 2004;6(6):R605-15.

186. Wang J, Wakeman TP, Lathia JD, Hjelmeland AB, Wang XF, White RR, Rich $\mathrm{JN}$, Sullenger BA. Notch promotes radioresistance of glioma stem cells. Stem Cells. 2010;28(1):17-28.

187. Gerby B, Clappier E, Armstrong F, Deswarte C, Calvo J, Poglio S, Soulier J, Boissel N, Leblanc T, Baruchel A, et al. Expression of CD34 and CD7 on human T-cell acute lymphoblastic leukemia discriminates functionally heterogeneous cell populations. Leukemia. 2011;25(8):1249-58.

188. Farnie G, Clarke RB, Spence K, Pinnock N, Brennan K, Anderson NG, Bundred NJ. Novel cell culture technique for primary ductal carcinoma in situ: role of Notch and epidermal growth factor receptor signaling pathways. J Natl Cancer Inst. 2007;99(8):616-27.

189. Fan X, Matsui W, Khaki L, Stearns D, Chun J, Li YM, Eberhart CG. Notch pathway inhibition depletes stem-like cells and blocks engraftment in embryonal brain tumors. Cancer Res. 2006;66(15):7445-52.

190. Fan X, Khaki L, Zhu TS, Soules ME, Talsma CE, Gul N, Koh C, Zhang J, Li YM, Maciaczyk J, et al. NOTCH pathway blockade depletes CD133-positive 
glioblastoma cells and inhibits growth of tumor neurospheres and xenografts. Stem Cells. 2010;28(1):5-16.

191. Pandya K, Meeke K, Clementz AG, Rogowski A, Roberts J, Miele L, Albain KS, Osipo C. Targeting both Notch and ErbB-2 signalling pathways is required for prevention of ErbB-2-positive breast tumour recurrence. $\mathrm{Br} J$ Cancer. 2011;105(6):796-806.

192. Kritikou E. miRNAs: tuning Notch responses. Nat Rev Genet. 2005;6(7):519-19.

193. Bartel DP. MicroRNAs: genomics, biogenesis, mechanism, and function. Cell. 2004;116(2):281-97.

194. Lu J, Getz G, Miska EA, Alvarez-Saavedra E, Lamb J, Peck D, Sweet-Cordero A, Ebert BL, Mak RH, Ferrando AA, et al. MicroRNA expression profiles classify human cancers. Nature. 2005;435(7043):834-8.

195. Kasinski AL, Slack FJ. Epigenetics and genetics. MicroRNAs en route to the clinic: progress in validating and targeting microRNAs for cancer therapy. Nat Rev Cancer. 2011;11(12):849-64.

196. Hu G, Drescher KM, Chen XM. Exosomal miRNAs: biological properties and therapeutic potential. Front Genet. 2012;3:56.

197. Yu F, Yao H, Zhu P, Zhang X, Pan Q, Gong C, Huang Y, Hu X, Su F, Lieberman J, et al. let-7 regulates self renewal and tumorigenicity of breast cancer cells. Cell. 2007;131(6):1109-23.

198. Shimono Y, Zabala M, Cho RW, Lobo N, Dalerba P, Qian D, Diehn M, Liu H, Panula SP, Chiao E, et al. Downregulation of miRNA-200c links breast cancer stem cells with normal stem cells. Cell. 2009;138(3):592-603.

199. Park IK, Qian D, Kiel M, Becker MW, Pihalja M, Weissman IL, Morrison SJ, Clarke MF. Bmi-1 is required for maintenance of adult self-renewing haematopoietic stem cells. Nature. 2003;423(6937):302-5.

200. Siddique HR, Parray A, Zhong W, Karnes RJ, Bergstralh EJ, Koochekpour S, Rhim JS, Konety BR, Saleem M. BMI1, stem cell factor acting as novel serumbiomarker for Caucasian and African-American prostate cancer. PLoS One. 2013:8(1):e52993.

201. Wellner U, Schubert J, Burk UC, Schmalhofer O, Zhu F, Sonntag A, Waldvogel B, Vannier C, Darling D, zur Hausen A, et al. The EMT-activator ZEB1 promotes tumorigenicity by repressing stemness-inhibiting microRNAs. Nat Cell Biol. 2009;11(12):1487-95.

202. Liu C, Kelnar K, Liu B, Chen X, Calhoun-Davis T, Li H, Patrawala L, Yan H, Jeter $\mathrm{C}$, Honorio $\mathrm{S}$, et al. The microRNA miR-34a inhibits prostate cancer stem cells and metastasis by directly repressing CD44. Nat Med. 2011;17(2):211-5.

203. Giannoni E, Bianchini F, Masieri L, Serni S, Torre E, Calorini L, Chiarugi P. Reciprocal activation of prostate cancer cells and cancer-associated fibroblasts stimulates epithelial-mesenchymal transition and cancer stemness. Cancer Res. 2010;70(17):6945-56.

204. Niopoulos D, Hirsch HA, Wang G, Struhl K. Inducible formation of breast cancer stem cells and their dynamic equilibrium with non-stem cancer cells via IL6 secretion. Proc Natl Acad Sci U S A. 2011;108(4):1397-402.

205. Hawsawi NM, Ghebeh H, Hendrayani SF, Tulbah A, Al-Eid M, Al-Tweigeri T, Ajarim D, Alaiya A, Dermime S, Aboussekhra A. Breast carcinoma-associated fibroblasts and their counterparts display neoplastic-specific changes. Cancer Res. 2008;68(8):2717-25.

206. Cartwright P, McLean C, Sheppard A, Rivett D, Jones K, Dalton S. LIF/STAT3 controls ES cell self-renewal and pluripotency by a Myc-dependent mechanism. Development. 2005;132(5):885-96.

207. Korkaya H, Kim Gl, Davis A, Malik F, Henry NL, Ithimakin S, Quraishi AA, Tawakkol N, D'Angelo R, Paulson AK, et al. Activation of an IL6 inflammatory loop mediates trastuzumab resistance in HER2+ breast cancer by expanding the cancer stem cell population. Mol Cell. 2012;47(4):570-84.

208. Liu S, Ginestier C, Ou SJ, Clouthier SG, Patel SH, Monville F, Korkaya H, Heath A, Dutcher J, Kleer CG, et al. Breast cancer stem cells are regulated by mesenchymal stem cells through cytokine networks. Cancer Res. 2011;71(2):614-24.

209. Muller AJ, Scherle PA. Targeting the mechanisms of tumoral immune tolerance with small-molecule inhibitors. Nat Rev Cancer. 2006;6(8):613-25.

210. Ginestier C, Liu S, Diebel ME, Korkaya H, Luo M, Brown M, Wicinski J, Cabaud O, Charafe-Jauffret E, Birnbaum D, et al. CXCR1 blockade selectively targets human breast cancer stem cells in vitro and in xenografts. J Clin Invest. 2010;120(2):485-97.

211. Bhola NE, Balko JM, Dugger TC, Kuba MG, Sanchez V, Sanders M, Stanford J, Cook RS, Arteaga CL. TGF-beta inhibition enhances chemotherapy action against triple-negative breast cancer. J Clin Invest. 2013;123(3):1348-58.

212. Blackburn EH, Gall JG. A tandemly repeated sequence at the termini of the extrachromosomal ribosomal RNA genes in Tetrahymena. J Mol Biol. 1978; 120(1):33-53.
213. Perez-Caro M, Cobaleda C, Gonzalez-Herrero I, Vicente-Duenas C, BermejoRodriguez C, Sanchez-Beato M, Orfao A, Pintado B, Flores T, Sanchez-Martin $M$, et al. Cancer induction by restriction of oncogene expression to the stem cell compartment. EMBO J. 2009;28(1):8-20.

214. Shay JW, Wright WE. Telomeres and telomerase in normal and cancer stem cells. FEBS Lett. 2010;584(17):3819-25.

215. Xu Y, He K, Goldkorn A. Telomerase targeted therapy in cancer and cancer stem cells. Clin Adv Hematol Oncol. 2011;9(6):442-55.

216. Herbert BS, Gellert GC, Hochreiter A, Pongracz K, Wright WE, Zielinska D, Chin AC, Harley CB, Shay JW, Gryaznov SM. Lipid modification of GRN163, an N3' $\rightarrow$ P5' thio-phosphoramidate oligonucleotide, enhances the potency of telomerase inhibition. Oncogene. 2005;24(33):5262-8.

217. Serrano D, Bleau AM, Fernandez-Garcia I, Fernandez-Marcelo T, Iniesta P, Ortiz-de-Solorzano C, Calvo A. Inhibition of telomerase activity preferentially targets aldehyde dehydrogenase-positive cancer stem-like cells in lung cancer. Mol Cancer. 2011;10:96

218. Marian CO, Cho SK, McEllin BM, Maher EA, Hatanpaa KJ, Madden CJ, Mickey BE, Wright WE, Shay JW, Bachoo RM. The telomerase antagonist, imetelstat, efficiently targets glioblastoma tumor-initiating cells leading to decreased proliferation and tumor growth. Clin Cancer Res. 2010;16(1):154-63.

219. Ott M, Gogvadze V, Orrenius S, Zhivotovsky B. Mitochondria, oxidative stress and cell death. Apoptosis. 2007;12(5):913-22.

220. Guo YL, Chakraborty S, Rajan SS, Wang R, Huang F. Effects of oxidative stress on mouse embryonic stem cell proliferation, apoptosis, senescence, and self-renewal. Stem Cells Dev. 2010;19(9):1321-31.

221. Maraldi T. Natural Compounds as Modulators of NADPH Oxidases. Oxid Med Cell Longev. 2013;2013:10.

222. Zhang X, Rielland M, Yalcin S, Ghaffari S. Regulation and function of FoxO transcription factors in normal and cancer stem cells: what have we learned? Curr Drug Targets. 2011;12(9):1267-83.

223. Acharya A, Das I, Chandhok D, Saha T. Redox regulation in cancer: a doubleedged sword with therapeutic potential. Oxid Med Cell Longev. 2010;3(1):23-34.

224. Diehn M, Cho RW, Lobo NA, Kalisky T, Dorie MJ, Kulp AN, Qian D, Lam JS, Ailles $L E$, Wong $M$, et al. Association of reactive oxygen species levels and radioresistance in cancer stem cells. Nature. 2009;458(7239):780-3.

225. Fan S, Meng Q, Saha T, Sarkar FH, Rosen EM. Low concentrations of diindolylmethane, a metabolite of indole-3-carbinol, protect against oxidative stress in a BRCA1-dependent manner. Cancer Res. 2009:69(15):6083-91.

226. Fan S, Meng Q, Auborn K, Carter T, Rosen EM. BRCA1 and BRCA2 as molecular targets for phytochemicals indole-3-carbinol and genistein in breast and prostate cancer cells. Br J Cancer. 2006;94(3):407-26.

227. Banerjee S, Li Y, Wang Z, Sarkar FH. Multi-targeted therapy of cancer by genistein. Cancer Lett. 2008;269(2):226-42.

228. Ayyasamy V, Owens KM, Desouki MM, Liang P, Bakin A, Thangaraj K, Buchsbaum DJ, LoBuglio AF, Singh KK. Cellular model of Warburg effect identifies tumor promoting function of UCP2 in breast cancer and its suppression by genipin. PLoS One. 2011;6(9):e24792.

229. Brooks JD. Translational genomics: the challenge of developing cancer biomarkers. Genome Res. 2012;22(2):183-7.

230. De Gruttola VG, Clax P, DeMets DL, Downing GJ, Ellenberg SS, Friedman L, Gail MH, Prentice R, Wittes J, Zeger SL. Considerations in the evaluation of surrogate endpoints in clinical trials. summary of a National Institutes of Health workshop. Control Clin Trials. 2001;22(5):485-502.

231. Henry NL, Hayes DF. Cancer biomarkers. Mol Oncol. 2012;6(2):140-6.

232. Nilsson J, Skog J, Nordstrand A, Baranov V, Mincheva-Nilsson L, Breakefield $\mathrm{XO}$, Widmark A. Prostate cancer-derived urine exosomes: a novel approach to biomarkers for prostate cancer. Br J Cancer. 2009;100(10):1603-7.

233. Logozzi M, De Milito A, Lugini L, Borghi M, Calabro L, Spada M, Perdicchio M, Marino ML, Federici C, lessi E, et al. High levels of exosomes expressing CD63 and caveolin-1 in plasma of melanoma patients. PLoS One. 2009:4(4)::5219.

234. Yoshioka Y, Konishi Y, Kosaka N, Katsuda T, Kato T, Ochiya T. Comparative marker analysis of extracellular vesicles in different human cancer types. J Extracell Vesicles. 2013;2.

235. Skog J, Wurdinger T, van Rijn S, Meijer DH, Gainche L, Sena-Esteves M, Curry Jr WT, Carter BS, Krichevsky AM, Breakefield XO. Glioblastoma microvesicles transport RNA and proteins that promote tumour growth and provide diagnostic biomarkers. Nat Cell Biol. 2008;10(12):1470-6.

236. Graner MW, Alzate O, Dechkovskaia AM, Keene JD, Sampson JH, Mitchell DA, Bigner DD. Proteomic and immunologic analyses of brain tumor exosomes. Faseb J. 2009;23(5):1541-57. 
237. Brase JC, Johannes M, Schlomm T, Falth M, Haese A, Steuber T, Beissbarth $T$, Kuner R, Sultmann $\mathrm{H}$. Circulating miRNAs are correlated with tumor progression in prostate cancer. Int J Cancer. 2011;128(3):608-16.

238. Tanaka Y, Kamohara H, Kinoshita K, Kurashige J, Ishimoto T, Iwatsuki M, Watanabe $\mathrm{M}$, Baba $\mathrm{H}$. Clinical impact of serum exosomal microRNA-21 as a clinical biomarker in human esophageal squamous cell carcinoma. Cancer. 2013;119(6):1159-67

239. Takeshita N, Hoshino I, Mori M, Akutsu Y, Hanari N, Yoneyama Y, Ikeda N, Isozaki Y, Maruyama T, Akanuma N, et al. Serum microRNA expression profile: miR-1246 as a novel diagnostic and prognostic biomarker for oesophageal squamous cell carcinoma. Br J Cancer. 2013;108(3):644-52.

240. Costa-Silva B, Aiello NM, Ocean AJ, Singh S, Zhang H, Thakur BK, Becker A, Hoshino A, Mark MT, Molina H, et al. Pancreatic cancer exosomes initiate pre-metastatic niche formation in the liver. Nat Cell Biol. 2015;17(6):816-26.

241. Grange C, Tapparo M, Collino F, Vitillo L, Damasco C, Deregibus MC, Tetta C, Bussolati B, Camussi G. Microvesicles released from human renal cancer stem cells stimulate angiogenesis and formation of lung premetastatic niche. Cancer Res. 2011;71(15):5346-56.

242. Tommelein J, Verset L, Boterberg T, Demetter P, Bracke M, De Wever O. Cancer-associated fibroblasts connect metastasis-promoting communication in colorectal cancer. Front Oncol. 2015;5:63.

243. Tsujino T, Seshimo I, Yamamoto H, Ngan CY, Ezumi K, Takemasa I, Ikeda M, Sekimoto M, Matsuura N, Monden M. Stromal myofibroblasts predict disease recurrence for colorectal cancer. Clin Cancer Res. 2007;13(7):2082-90.

244. Torres S, Bartolome RA, Mendes M, Barderas R, Fernandez-Acenero MJ, Pelaez-Garcia A, Pena C, Lopez-Lucendo M, Villar-Vazquez R, de Herreros AG, et al. Proteome profiling of cancer-associated fibroblasts identifies novel proinflammatory signatures and prognostic markers for colorectal cancer. Clin Cancer Res. 2013;19(21):6006-19.

245. Henry LR, Lee HO, Lee JS, Klein-Szanto A, Watts P, Ross EA, Chen WT, Cheng JD. Clinical implications of fibroblast activation protein in patients with colon cancer. Clin Cancer Res. 2007;13(6):1736-41.

246. Saigusa S, Toiyama Y, Tanaka K, Yokoe T, Okugawa Y, Fujikawa H, Matsusita K, Kawamura M, Inoue Y, Miki C, et al. Cancer-associated fibroblasts correlate with poor prognosis in rectal cancer after chemoradiotherapy. Int J Oncol. 2011;38(3):655-63.

247. Ock CY, Lee KW, Kim JW, Kim JS, Kim TY, Lee KH, Han SW, Im SA, Kim TY, Kim WH, et al. Optimal patient selection for Trastuzumab Treatment in HER2-positive advanced gastric cancer. Clin Cancer Res. 2015;21(11):2520-9.

248. Tchou J, Kossenkov AV, Chang L, Satija C, Herlyn M, Showe LC, Pure E. Human breast cancer associated fibroblasts exhibit subtype specific gene expression profiles. BMC Med Genomics. 2012;5:39.

249. Jin L, Hope KJ, Zhai Q, Smadja-Joffe F, Dick JE. Targeting of CD44 eradicates human acute myeloid leukemic stem cells. Nat Med. 2006;12(10):1167-74.

250. Jansen B, Schlagbauer-Wadl H, Brown BD, Bryan RN, van Elsas A, Muller M, Wolff K, Eichler HG, Pehamberger $\mathrm{H}$. bcl-2 antisense therapy chemosensitizes human melanoma in SCID mice. Nat Med. 1998;4(2):232-4.

251. Paoluzzi L, Gonen M, Gardner JR, Mastrella J, Yang D, Holmlund J, Sorensen M, Leopold L, Manova K, Marcucci G, et al. Targeting Bcl-2 family members with the $\mathrm{BH} 3$ mimetic AT-101 markedly enhances the therapeutic effects of chemotherapeutic agents in in vitro and in vivo models of B-cell lymphoma. Blood. 2008;111(11):5350-8.

252. Wang G, Nikolovska-Coleska Z, Yang CY, Wang R, Tang G, Guo J, Shangary S, Qiu S, Gao W, Yang D, et al. Structure-based design of potent small-molecule inhibitors of anti-apoptotic BCl-2 proteins. J Med Chem. 2006;49(21):6139-42.

253. Tse C, Shoemaker AR, Adickes J, Anderson MG, Chen J, Jin S, Johnson EF, Marsh KC, Mitten MJ, Nimmer P, et al. ABT-263: a potent and orally bioavailable Bcl-2 family inhibitor. Cancer Res. 2008;68(9):3421-8.

254. Trudel S, Li ZH, Rauw J, Tiedemann RE, Wen XY, Stewart AK. Preclinical studies of the pan-Bcl inhibitor obatoclax (GX015-070) in multiple myeloma. Blood. 2007;109(12):5430-8.

255. Wei J, Stebbins JL, Kitada S, Dash R, Placzek W, Rega MF, Wu B, Cellitti J, Zhai D, Yang L, et al. Bl-97C1, an optically pure Apogossypol derivative as pan-active inhibitor of antiapoptotic B-cell lymphoma/leukemia-2 (Bcl-2) family proteins. J Med Chem. 2010;53(10):4166-76.

256. Lathia JD, Gallagher J, Heddleston JM, Wang J, Eyler CE, Macswords J, Wu Q, Vasanji A, McLendon RE, Hjelmeland AB, et al. Integrin alpha 6 regulates glioblastoma stem cells. Cell Stem Cell. 2010;6(5):421-32.

257. van der Horst $G$, van den Hoogen C, Buijs JT, Cheung H, Bloys $H$, Pelger RC, Lorenzon G, Heckmann B, Feyen J, Pujuguet P, et al. Targeting of alpha(v)integrins in stem/progenitor cells and supportive microenvironment impairs bone metastasis in human prostate cancer. Neoplasia. 2011;13(6):516-25.
258. Burke PA, DeNardo SJ, Miers LA, Lamborn KR, Matzku S, DeNardo GL. Cilengitide targeting of alpha(v)beta(3) integrin receptor synergizes with radioimmunotherapy to increase efficacy and apoptosis in breast cancer xenografts. Cancer Res. 2002;62(15):4263-72.

259. Eskens FA, Dumez H, Hoekstra R, Perschl A, Brindley C, Bottcher S, Wynendaele W, Drevs J, Verweij J, van Oosterom AT. Phase I and pharmacokinetic study of continuous twice weekly intravenous administration of Cilengitide (EMD 121974), a novel inhibitor of the integrins alphavbeta3 and alphavbeta5 in patients with advanced solid tumours. Eur J Cancer. 2003;39(7):917-26.

260. Ricart AD, Tolcher AW, Liu G, Holen K, Schwartz G, Albertini M, Weiss G, Yazji $\mathrm{S}, \mathrm{Ng}$ C, Wilding G. Volociximab, a chimeric monoclonal antibody that specifically binds alpha5beta1 integrin: a phase I, pharmacokinetic, and biological correlative study. Clin Cancer Res. 2008;14(23):7924-9.

261. Stoeltzing O, Liu W, Reinmuth N, Fan F, Parry GC, Parikh AA, McCarty MF, Bucana CD, Mazar AP, Ellis LM. Inhibition of integrin alpha5beta1 function with a small peptide (ATN-161) plus continuous 5-FU infusion reduces colorectal liver metastases and improves survival in mice. Int J Cancer. 2003; 104(4):496-503

262. O'Callaghan K, Kuliopulos A, Covic L. Turning receptors on and off with intracellular pepducins: new insights into G-protein-coupled receptor drug development. J Biol Chem. 2012;287(16):12787-96.

263. Weisberg E, Azab AK, Manley PW, Kung AL, Christie AL, Bronson R, Ghobrial IM, Griffin JD. Inhibition of CXCR4 in CML cells disrupts their interaction with the bone marrow microenvironment and sensitizes them to nilotinib. Leukemia. 2012;26(5):985-90.

264. Guleng B, Tateishi K, Ohta M, Kanai F, Jazag A, ljichi H, Tanaka Y, Washida M, Morikane K, Fukushima Y, et al. Blockade of the stromal cell-derived factor$1 / C X C R 4$ axis attenuates in vivo tumor growth by inhibiting angiogenesis in a vascular endothelial growth factor-independent manner. Cancer Res. 2005;65(13):5864-71.

265. Gordon MS, Margolin K, Talpaz M, Sledge Jr GW, Holmgren E, Benjamin R, Stalter S, Shak S, Adelman D. Phase I safety and pharmacokinetic study of recombinant human anti-vascular endothelial growth factor in patients with advanced cancer. J Clin Oncol. 2001;19(3):843-50.

266. Wedge SR, Kendrew J, Hennequin LF, Valentine PJ, Barry ST, Brave SR, Smith NR, James NH, Dukes M, Curwen JO, et al. AZD2171: a highly potent, orally bioavailable, vascular endothelial growth factor receptor-2 tyrosine kinase inhibitor for the treatment of cancer. Cancer Res. 2005;65(10):4389-400.

267. ClinicalTrials.gov. https://www.clinicaltrials.gov (2016). Accessed 18 Feb 2016.

268. McCaig C, Duval C, Hemers E, Steele I, Pritchard DM, Przemeck S, Dimaline $\mathrm{R}$, Ahmed S, Bodger K, Kerrigan DD, et al. The role of matrix metalloproteinase-7 in redefining the gastric microenvironment in response to Helicobacter pylori. Gastroenterology. 2006;130(6):1754-63.

269. Dihlmann S, Siermann A, von Knebel DM. The nonsteroidal antiinflammatory drugs aspirin and indomethacin attenuate beta-catenin/TCF-4 signaling. Oncogene. 2001;20(5):645-53.

270. Hawcroft G, Gardner SH, Hull MA. Activation of peroxisome proliferatoractivated receptor gamma does not explain the antiproliferative activity of the nonsteroidal anti-inflammatory drug indomethacin on human colorectal cancer cells. J Pharmacol Exp Ther. 2003;305(2):632-7.

271. Chen B, Dodge ME, Tang W, Lu J, Ma Z, Fan CW, Wei S, Hao W, Kilgore J, Williams NS, et al. Small molecule-mediated disruption of Wnt-dependent signaling in tissue regeneration and cancer. Nat Chem Biol. 2009;5(2):100-7.

272. Huang SM, Mishina YM, Liu S, Cheung A, Stegmeier F, Michaud GA, Charlat O, Wiellette E, Zhang Y, Wiessner S, et al. Tankyrase inhibition stabilizes axin and antagonizes Wnt signalling. Nature. 2009;461(7264):614-20.

273. Lepourcelet M, Chen YN, France DS, Wang H, Crews P, Petersen F, Bruseo C, Wood AW, Shivdasani RA. Small-molecule antagonists of the oncogenic Tcf/ beta-catenin protein complex. Cancer Cell. 2004;5(1):91-102.

274. Emami KH, Nguyen C, Ma H, Kim DH, Jeong KW, Eguchi M, Moon RT, Teo JL, Kim $\mathrm{HY}$, Moon SH, et al. A small molecule inhibitor of beta-catenin/CREB-binding protein transcription [corrected]. Proc Natl Acad Sci U S A. 2004;101(34):12682-7.

275. Von Hoff DD, LoRusso PM, Rudin CM, Reddy JC, Yauch RL, Tibes R, Weiss GJ, Borad MJ, Hann CL, Brahmer JR, et al. Inhibition of the hedgehog pathway in advanced basal-cell carcinoma. N Engl J Med. 2009;361(12):1164-72.

276. Kondapaka SB, Singh SS, Dasmahapatra GP, Sausville EA, Roy KK. Perifosine, a novel alkylphospholipid, inhibits protein kinase B activation. Mol Cancer Ther. 2003;2(11):1093-103.

277. Hirai H, Sootome H, Nakatsuru Y, Miyama K, Taguchi S, Tsujioka K, Ueno Y, Hatch H, Majumder PK, Pan BS, et al. MK-2206, an allosteric Akt inhibitor, 
enhances antitumor efficacy by standard chemotherapeutic agents or molecular targeted drugs in vitro and in vivo. Mol Cancer Ther. 2010;9(7): 1956-67.

278. Rhodes N, Heerding DA, Duckett DR, Eberwein DJ, Knick VB, Lansing TJ, McConnell RT, Gilmer TM, Zhang SY, Robell K, et al. Characterization of an Akt kinase inhibitor with potent pharmacodynamic and antitumor activity. Cancer Res. 2008;68(7):2366-74

279. Pal SK, Reckamp K, Yu H, Figlin RA. Akt inhibitors in clinical development for the treatment of cancer. Expert Opin Investig Drugs. 2010;19(11):1355-66.

280. Calvo SE, Compton AG, Hershman SG, Lim SC, Lieber DS, Tucker EJ, Laskowski A, Garone C, Liu S, Jaffe DB, et al. Molecular diagnosis of infantile mitochondrial disease with targeted next-generation sequencing. Sci Transl Med. 2012;4(118):118ra110.

281. Heitman J, Movva NR, Hall MN. Targets for cell cycle arrest by the immunosuppressant rapamycin in yeast. Science. 1991;253(5022):905-9.

282. Hidalgo M, Rowinsky EK. The rapamycin-sensitive signal transduction pathway as a target for cancer therapy. Oncogene. 2000;19(56):6680-6.

283. Sedrani R, Cottens S, Kallen J, Schuler W. Chemical modification of rapamycin: the discovery of SDZ RAD. Transplant Proc. 1998;30(5):2192-4.

284. Mita M, Sankhala K, Abdel-Karim I, Mita A, Giles F. Deforolimus (AP23573) a novel mTOR inhibitor in clinical development. Expert Opin Investig Drugs. 2008;17(12):1947-54

285. Bhagwat SV, Gokhale PC, Crew AP, Cooke A, Yao Y, Mantis C, Kahler J, Workman J, Bittner M, Dudkin L, et al. Preclinical characterization of OSI-027, a potent and selective inhibitor of mTORC1 and mTORC2: distinct from rapamycin. Mol Cancer Ther. 2011;10(8):1394-406.

286. Feldman ME, Apsel B, Uotila A, Loewith R, Knight ZA, Ruggero D, Shokat KM. Active-site inhibitors of mTOR target rapamycin-resistant outputs of mTORC1 and mTORC2. PLoS Biol. 2009;7(2):e38.

287. Chresta CM, Davies BR, Hickson I, Harding T, Cosulich S, Critchlow SE, Vincent JP, Ellston R, Jones D, Sini P, et al. AZD8055 is a potent, selective, and orally bioavailable ATP-competitive mammalian target of rapamycin kinase inhibitor with in vitro and in vivo antitumor activity. Cancer Res. 2010;70(1):288-98.

288. Hsieh AC, Liu Y, Edlind MP, Ingolia NT, Janes MR, Sher A, Shi EY, Stumpf CR, Christensen C, Bonham MJ, et al. The translational landscape of mTOR signalling steers cancer initiation and metastasis. Nature. 2012;485(7396):55-61.

289. Maira SM, Pecchi S, Huang A, Burger M, Knapp M, Sterker D, Schnell C, Guthy D, Nagel T, Wiesmann M, et al. Identification and characterization of NVP-BKM120, an orally available pan-class I PI3-kinase inhibitor. Mol Cancer Ther. 2012;11(2):317-28.

290. Ihle NT, Williams R, Chow S, Chew W, Berggren MI, Paine-Murrieta G, Minion DJ, Halter RJ, Wipf P, Abraham R, et al. Molecular pharmacology and antitumor activity of PX-866, a novel inhibitor of phosphoinositide-3-kinase signaling. Mol Cancer Ther. 2004;3(7):763-72.

291. Folkes AJ, Ahmadi K, Alderton WK, Alix S, Baker SJ, Box G, Chuckowree IS, Clarke PA, Depledge P, Eccles SA, et al. The identification of 2-(1H-indazol-4-yl)-6-(4methanesulfonyl-piperazin-1-ylmethyl)-4-morpholin-4-yl-t hieno[3,2-d]pyrimidine (GDC-0941) as a potent, selective, orally bioavailable inhibitor of class I PI3 kinase for the treatment of cancer. J Med Chem. 2008;51(18):5522-32.

292. Herman SE, Gordon AL, Wagner AJ, Heerema NA, Zhao W, Flynn JM, Jones J, Andritsos L, Puri KD, Lannutti BJ, et al. Phosphatidylinositol 3-kinase-delta inhibitor CAL-101 shows promising preclinical activity in chronic lymphocytic leukemia by antagonizing intrinsic and extrinsic cellular survival signals. Blood. 2010;116(12):2078-88.

293. Garlich JR, De P, Dey N, Su JD, Peng X, Miller A, Murali R, Lu Y, Mills GB, Kundra $V$, et al. A vascular targeted pan phosphoinositide 3-kinase inhibitor prodrug, SF1126, with antitumor and antiangiogenic activity. Cancer Res. 2008;68(1):206-15.

294. Maira SM, Stauffer F, Brueggen J, Furet P, Schnell C, Fritsch C, Brachmann S, Chene P, De Pover A, Schoemaker K, et al. Identification and characterization of NVP-BEZ235, a new orally available dual phosphatidylinositol 3-kinase/mammalian target of rapamycin inhibitor with potent in vivo antitumor activity. Mol Cancer Ther. 2008;7(7):1851-63.

295. Prasad G, Sottero T, Yang X, Mueller S, James CD, Weiss WA, Polley MY, Ozawa T, Berger MS, Aftab DT, et al. Inhibition of PI3K/mTOR pathways in glioblastoma and implications for combination therapy with temozolomide. Neuro Oncol. 2011;13(4):384-92.

296. Sutherlin DP, Bao L, Berry M, Castanedo G, Chuckowree I, Dotson J, Folks A, Friedman L, Goldsmith R, Gunzner J, et al. Discovery of a potent, selective, and orally available class I phosphatidylinositol 3-kinase (PI3K)/mammalian target of rapamycin (mTOR) kinase inhibitor (GDC-0980) for the treatment of cancer. J Med Chem. 2011:54(21):7579-87.

297. Knight ZA, Gonzalez B, Feldman ME, Zunder ER, Goldenberg DD, Williams O, Loewith R, Stokoe D, Balla A, Toth B, et al. A pharmacological map of the PI3-K family defines a role for p110alpha in insulin signaling. Cell. 2006;125(4):733-47.

298. Liu J, Sato C, Cerletti M, Wagers A. Notch signaling in the regulation of stem cell self-renewal and differentiation. Curr Top Dev Biol. 2010;92:367-409.

299. Aste-Amezaga M, Zhang N, Lineberger JE, Arnold BA, Toner TJ, Gu M, Huang L, Vitelli S, Vo KT, Haytko P, et al. Characterization of Notch1 antibodies that inhibit signaling of both normal and mutated Notch1 receptors. PLoS One. 2010;5(2):e9094.

300. Dovey HF, John V, Anderson JP, Chen LZ, de Saint AP, Fang LY, Freedman SB, Folmer B, Goldbach E, Holsztynska E, et al. Functional gamma-secretase inhibitors reduce beta-amyloid peptide levels in brain. J Neurochem. 2001;76(1):173-81.

301. Lewis HD, Leveridge M, Strack PR, Haldon CD, O'Neil J, Kim H, Madin A, Hannam JC, Look AT, Kohl N, et al. Apoptosis in T cell acute lymphoblastic leukemia cells after cell cycle arrest induced by pharmacological inhibition of notch signaling. Chem Biol. 2007;14(2):209-19.

302. Lanz TA, Karmilowicz MJ, Wood KM, Pozdnyakov N, Du P, Piotrowski MA, Brown TM, Nolan CE, Richter KE, Finley JE, et al. Concentration-dependent modulation of amyloid-beta in vivo and in vitro using the gamma-secretase inhibitor, LY-450139. J Pharmacol Exp Ther. 2006;319(2):924-33.

303. Asai A, Oshima Y, Yamamoto Y, Uochi TA, Kusaka H, Akinaga S, Yamashita Y, Pongracz K, Pruzan R, Wunder $\mathrm{E}$, et al. A novel telomerase template antagonist (GRN163) as a potential anticancer agent. Cancer Res. 2003; 63(14):3931-9.

304. Emmink BL, Van Houdt WJ, Vries RG, Hoogwater FJ, Govaert KM, Verheem A, Nijkamp MW, Steller EJ, Jimenez CR, Clevers H, et al. Differentiated human colorectal cancer cells protect tumor-initiating cells from irinotecan. Gastroenterology. 2011;141(1):269-78.

305. Shishido Y, Ueno S, Yamazaki R, Nagaoka M, Matsuzaki T. ABCG2 inhibitor YHO-13351 sensitizes cancer stem/initiating-like side population cells to irinotecan. Anticancer Res. 2013;33(4):1379-86.

306. Mellman I, Coukos G, Dranoff G. Cancer immunotherapy comes of age. Nature. 2011:480(7378):480-9.

307. Suntharalingam G, Perry MR, Ward S, Brett SJ, Castello-Cortes A, Brunner MD, Panoskaltsis N. Cytokine storm in a phase 1 trial of the anti-CD28 monoclonal antibody TGN1412. N Engl J Med. 2006;355(10):1018-28.

308. Brahmer JR, Drake CG, Wollner I, Powderly JD, Picus J, Sharfman WH, Stankevich E, Pons A, Salay TM, McMiller TL, et al. Phase I study of singleagent anti-programmed death-1 (MDX-1106) in refractory solid tumors: safety, clinical activity, pharmacodynamics, and immunologic correlates. J Clin Oncol. 2010;28(19):3167-75.

\section{Submit your next manuscript to BioMed Central and we will help you at every step:}

- We accept pre-submission inquiries

- Our selector tool helps you to find the most relevant journal

- We provide round the clock customer support

- Convenient online submission

- Thorough peer review

- Inclusion in PubMed and all major indexing services

- Maximum visibility for your research

Submit your manuscript at www.biomedcentral.com/submit 